\title{
Photochemical trajectory modeling studies of the North Atlantic region during August 1993
}

\author{
Oliver Wild, ${ }^{1}$ Katharine S. Law, ${ }^{1}$ Daniel S. McKenna, ${ }^{2,3}$ Brian J. Bandy, ${ }^{4}$ \\ Stuart A. Penkett, ${ }^{4}$ and John A. Pyle ${ }^{1}$
}

\begin{abstract}
A Lagrangian photochemical trajectory model has been used to assess the factors affecting $\mathrm{O}_{3}$ production during transport of polluted air masses across the North Atlantic Ocean. Sensitivity studies have been performed along idealized trajectories, and it is found that the potential impact of North American emission sources is maximized by transport of air at high altitudes, in drier conditions and in conditions where mixing of the air with background air masses is relatively limited. Measurements taken from the NCAR King Air aircraft as part of the North Atlantic Regional Experiment (NARE) August 1993 intensive have been used to initialize forward trajectories, calculated using European Centre for Medium-Range Weather Forecasting analyzed wind fields, from eastern North America to assess $\mathrm{O}_{3}$ production over the Atlantic during this period. The effects of dilution of a polluted air parcel with air from the upper troposphere have also been studied, and the contribution of photochemical $\mathrm{O}_{3}$ production to the air mass composition is found to be smaller than that of dilution, particularly for long trajectories and for conditions where dilution is relatively rapid or involves air from the stratosphere. Measurements taken from the Meteorological Research Flight Hercules aircraft over the eastern Atlantic as part of the Oxidizing Capacity of the Tropospheric Atmosphere campaign have been examined in the light of these studies. A backward trajectory analysis has been performed from one of the vertical profiles taken off the coast of Portugal on August 31, 1993, to assess the origin of the different air masses intercepted. While the lower levels are characteristic of air from the European boundary layer advected over the ocean, the upper levels show strong evidence for anthropogenic influence from North American sources, with elevated levels of $\mathrm{O}_{3}$, $\mathrm{NO}_{y}, \mathrm{CO}$, and aerosol. Although it cannot be concluded that this air mass definitely originated from over North America, the measured concentrations are shown to be consistent with those for an air mass from this source region experiencing some mixing with air masses in the upper troposphere.
\end{abstract}

\section{Introduction}

Away from coastal regions, the marine boundary layer over the North Atlantic Ocean is thought to be relatively free of pollutants of anthropogenic origin. However, the midtroposphere over the ocean may be strongly influenced by emissions from North America or Europe; the effect of such continental emissions on

\footnotetext{
${ }^{1}$ Centre for Atmospheric Science, Department of Chemistry, University of Cambridge, England.

${ }^{2}$ Atmospheric Chemistry Group, Meteorological Research Flight, DRA Farnborough, Hampshire, England.

${ }^{3}$ Now at the Institut für Chemie und Dynamik der Geosphäre, KFA Forschungszentrum Jülich, Jülich, Germany.

${ }^{4}$ School of Environmental Sciences, University of East Anglia, Norwich, England.

Copyright 1996 by the American Geophysical Union.

Paper number 96JD00837.

0148-0227/96/96JD-00837\$09.00
}

the oxidizing capacity of air over the North Atlantic has yet to be fully assessed. Preliminary studies examining the transport of primary and secondary pollutants from North America out over the North Atlantic have indicated that the North American continent may provide as large a source of tropospheric $\mathrm{O}_{3}$ as the stratosphere during the summer months [Parrish et al., 1993]. The August 1993 intensive organized as part of the North Atlantic Regional Experiment (NARE) has provided further evidence for the transport of anthropogenic pollutants and ozone precursors from North American sources out over the Atlantic Ocean [Fehsenfeld et al., this issue]. The Oxidizing Capacity of the Tropospheric Atmosphere (OCTA) campaign over the central and eastern Atlantic [Volz-Thomas et al., 1994] was timed to coincide with the NARE intensive, greatly extending the region over which data were available and providing the opportunity to look more closely at long-distance transport processes from North America toward Europe. 
The factors affecting the variation in ozone levels over the ocean have recently been discussed. Ayers et al. [1992] have shown that in the unpolluted marine boundary layer of the southern hemisphere, the annual cycle of ozone can be attributed principally to photochemical destruction processes. In the polluted northern hemisphere the situation is more complex, and it is expected that transport processes play a greater role in determining ozone concentrations in the midtroposphere, both by advection of polluted air from industrial regions and by transport of ozone down from the stratosphere [Levy et al., 1985]. Ozone variations over the eastern Atlantic have been considered by Doddridge et al. [1994], who highlight the strong control that meteorological factors play in determining ozone concentrations. Over the western Atlantic, Oltmans and Levy [1992] described measurements at Bermuda and Barbados that indicate that surface ozone is principally controlled by natural processes; subsequent measurements and analysis by Dickerson et al. [1995] have suggested that anthropogenic pollution from North America may also play a part in contributing to ozone episodes in the spring and early summer.

The aims of the present study are to build on this work by considering the potential for North American emissions to affect ozone levels over the eastern Atlantic close to Europe. First of all, results are presented from model sensitivity studies focusing on some of the chemical and physical processes affecting the composition of air masses crossing the North Atlantic and the potential for formation of secondary pollutants, ozone in particular. A case study is then presented considering air masses crossing the Atlantic from North America to Europe using calculated trajectories and chemical initializations based on NCAR King Air measurements taken as part of the NARE intensive in August 1993. The results of these studies are compared with a profile taken over the eastern Atlantic by the Meteorological Research Flight (MRF) Hercules at the end of August. Finally, the factors affecting ozone levels over the eastern Atlantic during this period are considered and the importance of these processes assessed.

\section{Meteorology}

The meteorological conditions over the western Atlantic have been described by Merrill and Moody [this issue]. Off the coast of Europe the conditions were characterized by a high-pressure system present over the northeastern Atlantic during the second half of August. From August 16 onward the mid-Atlantic high extended northeastward toward the British Isles, and after a brief cutoff on August 20-21, a ridge of high pressure was maintained over the North Atlantic until the beginning of September. This can be seen in the geopotential height of the $500-\mathrm{hPa}$ surface at noon on August 25, derived from the European Centre for Medium-Range
Weather Forecasting (ECMWF) analyzed wind fields; see Figure 1. During the same period, a number of lowpressure systems originating off the coast of Greenland tracked eastward around this ridge toward the European continent, taking paths as far north as Iceland. Low-pressure systems over Scandinavia and the Iberian Peninsula then forced air southward along the eastern flank of the high-pressure ridge. By August 30, the high pressure had moved over the United Kingdom and was edging northward; the pressure system did not move eastward over Europe until September 6.

The effect of the high-pressure ridge was to force warm air masses moving eastward from the North American coast northward, lifting them over cooler Arctic air masses. After passing around the anticyclone, the air subsided and moved southward again, toward or along the eastern seaboard of the Atlantic. For the measurement site at Izaña, Tenerife, and the aircraft profiles over the eastern Atlantic, the prevailing wind at the surface during the second half of August came from the north. The eastward movement of depressions from southern Greenland, via Iceland, to northern Europe led to a fluctuation in the original source of this air, alternating between Iceland and the region north of Scandinavia.

The meteorological situation in August 1993 appears somewhat unusual [Ratcliffe, 1993]. The maximum pressure associated with the mid-Atlantic high was located farther north than usual, between $45^{\circ}$ and $55^{\circ} \mathrm{N}$, for a period of 10 days; in most summers it is typically found between $35^{\circ}$ and $40^{\circ} \mathrm{N}$, which is liable to favor more direct westerly transport from North America. Situations of direct transport did occur a couple of times in the summers of 1992 and 1994, though typically lasted for only 3 or 4 days, rather shorter in duration than that of August 1993.

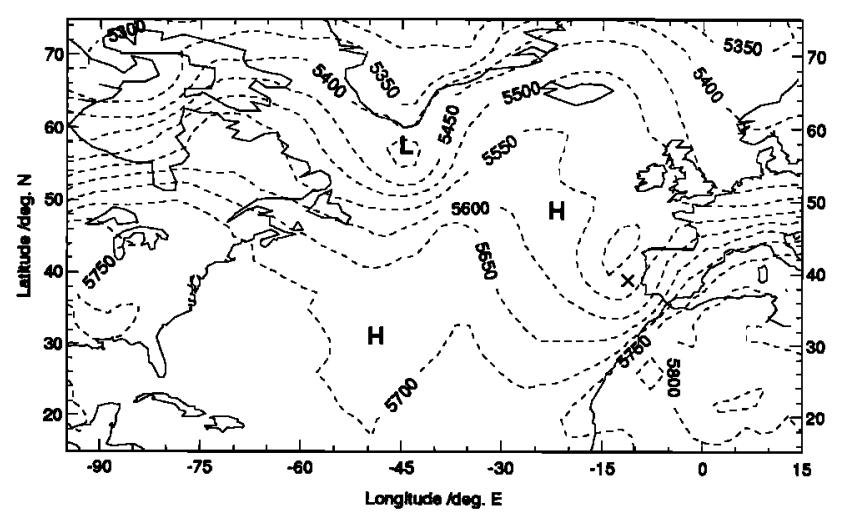

Figure 1. Geopotential height (in meters) of the 500$\mathrm{hPa}$ surface for noon on August 25 showing the prevailing meteorological conditions. The position of the MRF Hercules "Lisbon" profile is marked with a cross. The positions of the centers of low- and high-pressure systems at the surface are indictated by " $\mathrm{L}$ " and " $\mathrm{H}$ ", respectively. 


\section{Model Description}

In this study, a Lagrangian photochemical trajectory model has been used to follow the chemical changes occurring in air masses crossing the Atlantic. The model contains a detailed chemical scheme including hydrogen, oxygen, nitrogen, and methane chemistry, with reactions and rate constants taken from Atkinson et al. [1992] and additional data from DeMore et al. [1992]. The treatment of hydrocarbon chemistry is based on that of Hough [1991], which uses a "lumped molecule" approach with simplified oxidation schemes for representative hydrocarbons of each class. Photolysis rates are calculated using a two-stream isotropic approach adapted from that of Hough [1988]. Contributions to the actinic flux are calculated from the direct solar beam and from six successive orders of scattered light. A treatment of absorption and scattering due to clouds and aerosol particles is also included. A detailed description of the model is given by Wild [1995].

Surface emissions are introduced in the boundary layer from the Co-operative Programme for Monitoring and Evaluation of the Long Range Transmission of Air Pollutants in Europe (EMEP) emissions inventory [Simpson, 1992] for 1992 on a $150 \times 150 \mathrm{~km}$ grid over Europe, with seasonal and diurnal variations parameterized by Memmesheimer et al. [1991]. Emissions of $\mathrm{NO}_{x}, \mathrm{CO}$, and hydrocarbons are currently considered; non-methane hydrocarbon (NMHC) emissions use the RADM2 lumping scheme [Stockwell et al., 1990], and the species have been reapportioned into the present groupings by carbon mass. Dry deposition has been included in the boundary layer, with 1-m deposition velocities referenced to the center of the model layer. A simple first-order loss rate has been used for wet deposition, with a lifetime of 5 days close to the surface, increasing with altitude [Logan et al., 1981]. $\mathrm{HNO}_{3}$ is assumed to have a 2.5-day lifetime to account for its greater solubility [Law and Pyle, 1993]. In addition to these physical and chemical processes, a parameterization for the diurnal variation in the depth of the boundary layer has been included. For runs over Europe the urban boundary layer parameterization of Derwent and Hov [1982] has been used, with a depth of $300 \mathrm{~m}$ during the night rising to a maximum depth of $1300 \mathrm{~m}$ in the early afternoon.

\section{Cross-Atlantic Sensitivity Studies}

A series of sensitivity studies have been performed with idealized trajectories to assess the major processes affecting the composition of air masses crossing the North Atlantic from west to east. Ten-day isobaric trajectories at 300 and $900 \mathrm{hPa}$ have been considered, following the northern and southern routes shown in Figure 2a. The impact of altitude and latitude on the photochemical composition of an air parcel crossing the (a)

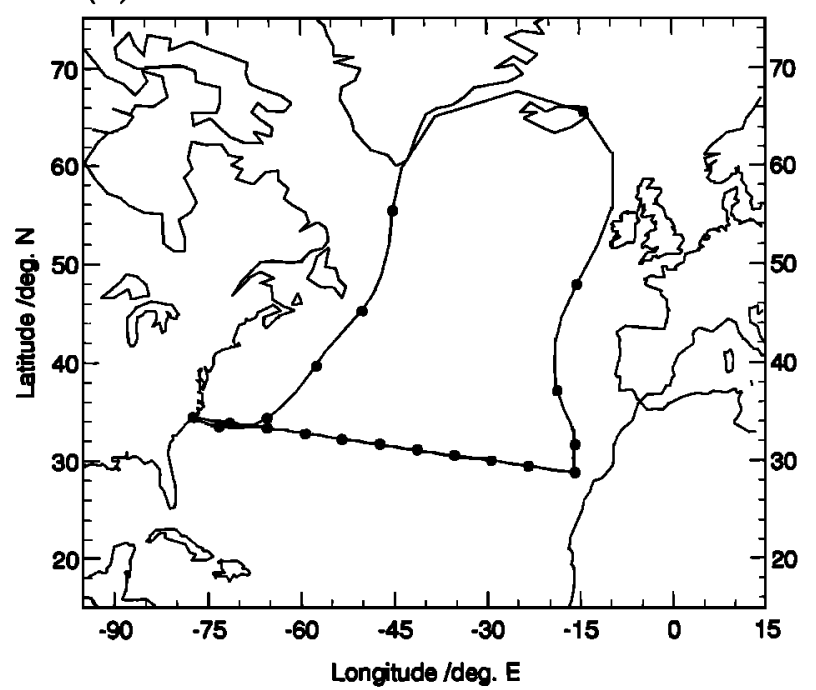

(b)

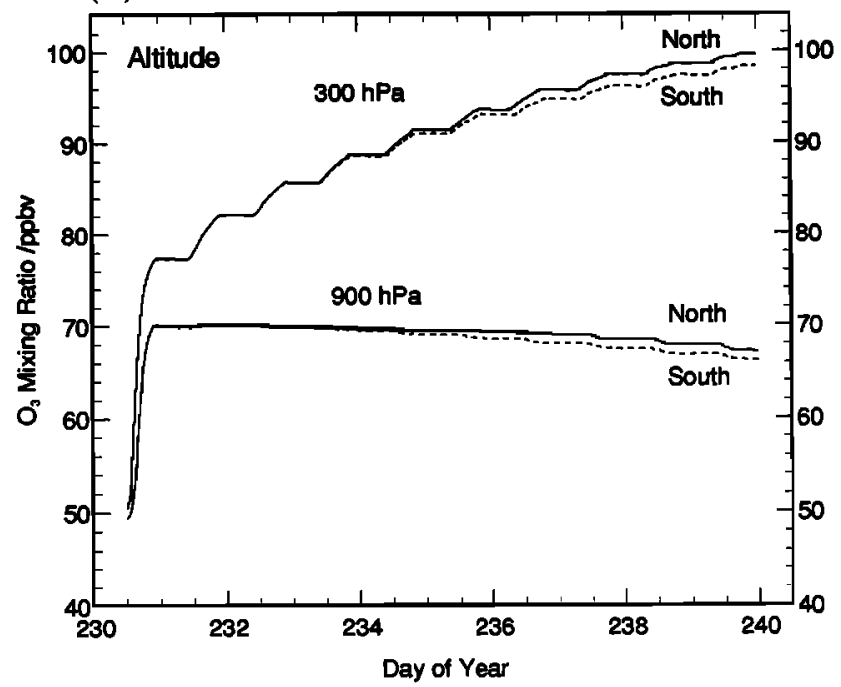

(c)

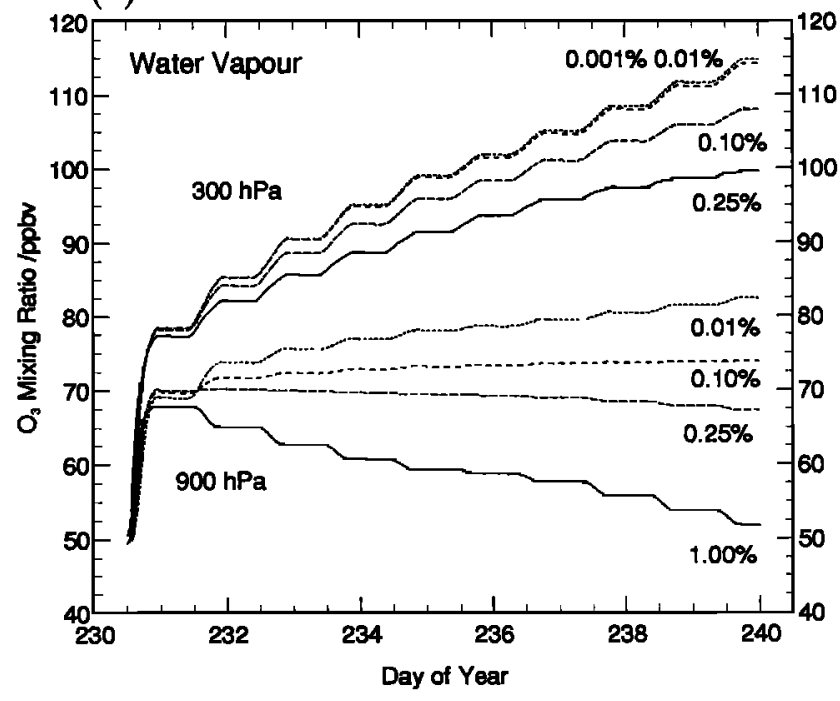

Figure 2. Ten-day back trajectories over the North Atlantic, showing (a) the northern and southern routes, with markers every 24 hours, and the impact on $\mathrm{O}_{3}$ production of (b) altitude and latitude, and (c) water vapor volume mixing ratio along these trajectories. 
Table 1. Initial Chemical Conditions (Expressed in Volume Mixing Ratio) Used for Sensitivity Studies Along Cross-Atlantic Trajectories

\begin{tabular}{cccccccc}
\hline $\mathrm{O}_{3}$ & $\mathrm{CH}_{4}$ & $\mathrm{CO}$ & $\mathrm{H}_{2} \mathrm{O}_{2}$ & $\mathrm{NO}_{x}$ & $\mathrm{HNO}_{3}$ & $\mathrm{H}_{2} \mathrm{O}$ & NMHC \\
\hline $50 \mathrm{ppbv}$ & $1.7 \mathrm{ppmv}$ & $300 \mathrm{ppbv}$ & $2.0 \mathrm{ppbv}$ & $2.0 \mathrm{ppbv}$ & $100 \mathrm{pptv}$ & $\mathbf{0 . 2 5 \%}$ & $35 \mathrm{ppbC}$ \\
\hline
\end{tabular}

NMHC, non methane hydrocarbon.

North Atlantic is addressed; the uplift of air as it moves northward is considered in the next section. The U.S. Standard Atmosphere (1976) was used to provide an $\mathrm{O}_{3}$ column, with diurnal mean temperatures of $273 \mathrm{~K}$ at $900 \mathrm{hPa}$ and $235 \mathrm{~K}$ at $300 \mathrm{hPa}$. A standard set of chemical concentrations were used to initialize the model with moderately polluted conditions typical of air downwind of an urban center, based on those from the photochemistry intercomparison of the Intergovernmental Panel on Climate Change (IPCC) [1995] (see Table 1) with the hydrocarbon species apportioned as shown in Table 2. The same chemical initializations have been used in these runs at both 300 and $900 \mathrm{hPa}$ unless stated otherwise. The effects of emissions, wet and dry deposition, and mixing of background air into the air parcel have been neglected.

\section{Latitude and Altitude}

Runs have been performed along the northern and southern routes at 300 and $900 \mathrm{hPa}$; the temperatures used at each altitude were assumed to be independent of latitude. The calculated $\mathrm{O}_{3}$ production along these isobaric trajectories is shown in Figure $2 \mathrm{~b}$. The difference between northern and southern routes is relatively small, about $1 \%$ at both altitudes, principally reflecting the difference in day length. Increasing the temperatures along the southern route by $10 \mathrm{~K}$ leads to an increase in $\mathrm{O}_{3}$ production of only about $4 \%$. It appears that the major influence on $\mathrm{O}_{3}$ production is the altitude at which the air parcel travels. Air parcels traveling at $900 \mathrm{hPa}$ display net $\mathrm{O}_{3}$ destruction after the first day, whereas those at $300 \mathrm{hPa}$ continue to exhibit $\mathrm{O}_{3}$ production over the full 10-day period. A budget analysis has been performed to assess the different chemical terms important for $\mathrm{O}_{3}$ production for both $300 \mathrm{hPa}$ and $900 \mathrm{hPa}$ northern trajectories on day 234 , the fifth day over the Atlantic, and fluxes through the relevant reactions are shown in Figure 3.

$\mathrm{O}_{3}$ is principally formed by the reactions $\mathrm{NO}+\mathrm{HO}_{2}$ and $\mathrm{NO}+\mathrm{RO}_{2}$ (where " $\mathrm{R}$ " represents an alkyl group), followed by $\mathrm{NO}_{2}$ photolysis, and destroyed by the reactions $\mathrm{HO}_{2}+\mathrm{O}_{3}$ and $\mathrm{O}\left({ }^{1} D\right)+\mathrm{H}_{2} \mathrm{O}$. Removal of $\mathrm{NO}_{2}$ to form $\mathrm{HNO}_{3}$ by reaction with $\mathrm{OH}$ radicals is slower at $300 \mathrm{hPa}$ than at $900 \mathrm{hPa}$ due to the pressure de- pendence of the reaction and to the lower proportion of $\mathrm{NO}_{x}$ as $\mathrm{NO}_{2}$; the subsequent photolysis of $\mathrm{HNO}_{3}$ to reform $\mathrm{NO}_{2}$ and $\mathrm{OH}$ radicals is $45 \%$ faster at $300 \mathrm{hPa}$ than at $900 \mathrm{hPa}$. Slower formation of $\mathrm{HNO}_{3}$ and more rapid removal leads to $\mathrm{NO}_{x}$ levels of 76 parts per trillion by volume (pptv) at $300 \mathrm{hPa}$ compared to $51 \mathrm{pptv}$ at $900 \mathrm{hPa}$ at noon on the fifth day (day 234). The reaction rate constant for $\mathrm{NO}+\mathrm{O}_{3}$ at $235 \mathrm{~K}$ is only $44 \%$ of that at $273 \mathrm{~K}$, while the rate constants for $\mathrm{NO}+\mathrm{HO}_{2}$ and $\mathrm{NO}+\mathrm{RO}_{2}$ are $10-15 \%$ faster than at $273 \mathrm{~K}$. This shifts the balance of NO oxidation toward the peroxy radical reactions; at noon these peroxy radical reactions account for $40 \%$ of $\mathrm{NO}$ oxidation at $300 \mathrm{hPa}$, compared to only $20 \%$ at $900 \mathrm{hPa}$, and hence the efficiency of $\mathrm{O}_{3}$ production per molecule of NO oxidized is greater at $300 \mathrm{hPa}$. The photolysis rate of $\mathrm{NO}_{2}$ is only $21 \%$ faster at $300 \mathrm{hPa}$, while NO oxidation is slower because the reduction in the $\mathrm{NO}+\mathrm{O}_{3}$ rate constant is not compensated by the increases in $\mathrm{NO}+\mathrm{HO}_{2}$ and $\mathrm{NO}+\mathrm{RO}_{2}$ rate constants; the $\mathrm{NO} / \mathrm{NO}_{2}$ ratio is therefore higher at $300 \mathrm{hPa}$ than at $900 \mathrm{hPa}$. Coupled with the $50 \%$ higher $\mathrm{NO}_{x}$ concentrations, the rate of $\mathrm{O}_{3}$ production resulting from oxidation of $\mathrm{NO}$ to $\mathrm{NO}_{2}$ is 5.5 times greater than at $900 \mathrm{hPa}$.

The rate constant for $\mathrm{O}_{3}$ destruction by $\mathrm{HO}_{2}+\mathrm{O}_{3}$ at $235 \mathrm{~K}$ is only $70 \%$ of that at $273 \mathrm{~K}$. However, the faster photolysis of $\mathrm{O}_{3}$ to form $\mathrm{O}\left({ }^{1} D\right)$ leads to 4 times as much $\mathrm{O}_{3}$ destruction by the $\mathrm{O}\left({ }^{1} D\right)+\mathrm{H}_{2} \mathrm{O}$ route, and hence the total rate of $\mathrm{O}_{3}$ destruction is 3.3 times greater at $300 \mathrm{hPa}$ than at $900 \mathrm{hPa}$. At $900 \mathrm{hPa}$ the destruction rate is greater than the production rate, and net $\mathrm{O}_{3}$ destruction occurs; the increase in the production rate at $300 \mathrm{hPa}$ is more than sufficient to offset the increased $\mathrm{O}_{3}$ destruction rate, leading to net $\mathrm{O}_{3}$ production at $300 \mathrm{hPa}$. As a consequence of the faster $\mathrm{NO}+\mathrm{HO}_{2}$ and $\mathrm{O}\left({ }^{1} D\right)+\mathrm{H}_{2} \mathrm{O}$ reactions which offset the loss due to $\mathrm{OH}+\mathrm{O}_{3}$ and $\mathrm{OH}+\mathrm{H}_{2} \mathrm{O}_{2}, \mathrm{OH}$ concentrations are twice as high at $300 \mathrm{hPa}$ as at $900 \mathrm{hPa}$. Note that this is due to the water vapor mixing ratio of $0.25 \%$ used in this study, rather high for $300 \mathrm{hPa}$. The high $\mathrm{OH}$ radical concentrations lead to more rapid oxidation of the hydrocarbons at $300 \mathrm{hPa}$, but note that $\mathrm{RO}_{2}$ concentrations are $60-95 \%$ of those at $900 \mathrm{hPa}$ due to the higher $\mathrm{NO}_{x}$ concentrations.

Table 2. Apportioning of Hydrocarbons by Carbon Mass Between Modeled NMHC Groupings

\begin{tabular}{llllllllll}
\hline $\mathrm{C}_{2} \mathrm{H}_{6}$ & $\mathrm{C}_{3} \mathrm{H}_{8}$ & $\mathrm{C}_{4} \mathrm{H}_{10}$ & $\mathrm{C}_{5} \mathrm{H}_{12}$ & $\mathrm{C}_{6} \mathrm{H}_{14}$ & $\mathrm{C}_{2} \mathrm{H}_{4}$ & $\mathrm{C}_{3} \mathrm{H}_{6}$ & $\mathrm{C}_{2} \mathrm{H}_{2}$ & $\mathrm{C}_{6} \mathrm{H}_{6}$ & $\mathrm{C}_{7} \mathrm{H}_{8}$ \\
\hline $21.0 \%$ & $12.6 \%$ & $2.1 \%$ & $0.85 \%$ & $0.85 \%$ & $33.6 \%$ & $10.5 \%$ & $12.6 \%$ & $4.2 \%$ & $1.7 \%$ \\
\hline
\end{tabular}


(a)

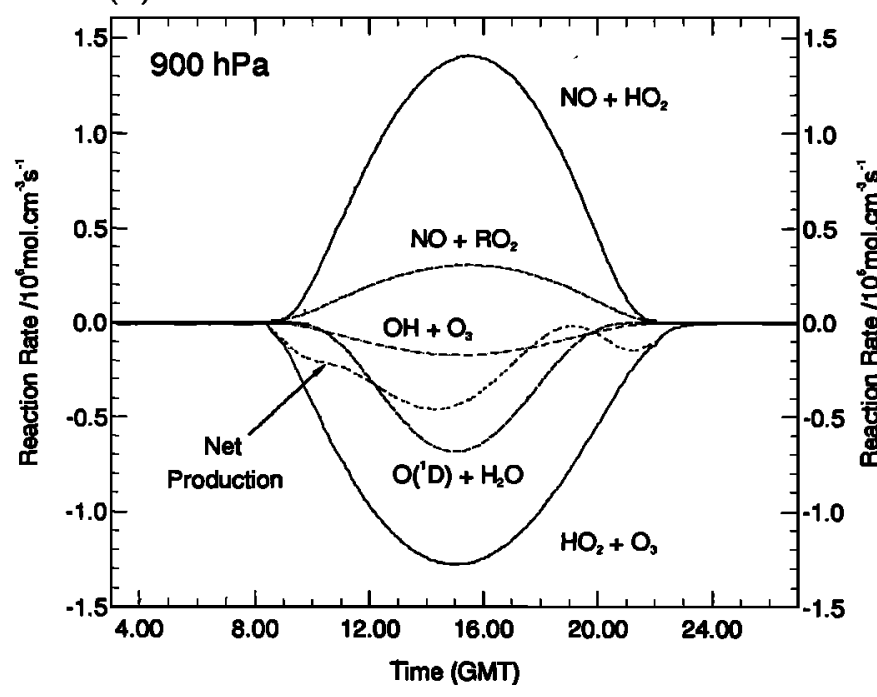

(b)

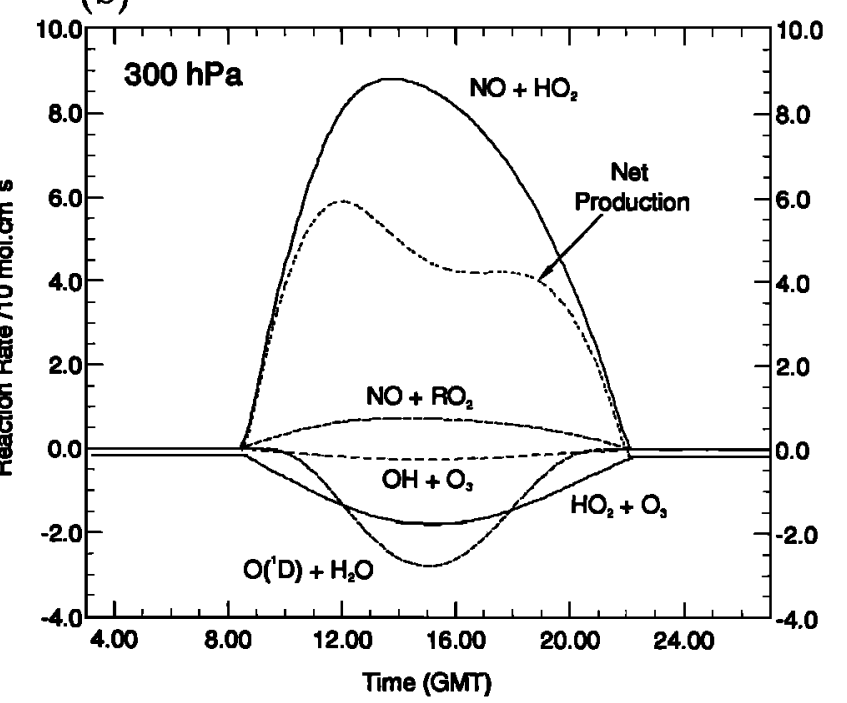

Figure 3. The budget of $\mathrm{O}_{3}$ production and loss rates for the fifth day (day 234) of the northern cross-Atlantic trajectory run at (a) 900 and (b) $300 \mathrm{hPa}$; note the different vertical scales. Times are given in UT, not local solar time.

\section{Water Vapor Content}

In the atmosphere, lower tropospheric air from the boundary layer has a water vapor volume mixing ratio in the region of $1.0-0.25 \%$, whereas in air at $300 \mathrm{hPa}$ it might typically be around $0.01 \%$ [Valentin, 1990]. An air parcel undergoing convection to $300 \mathrm{hPa}$ would be expected to dry out after condensation of the water vapor. To assess the effect on $\mathrm{O}_{3}$ production, the water vapor mixing ratio was varied along the northern isobaric trajectories between $1 \%$ and $0.001 \%$ at the two altitudes; see Figure 2c. Drier air masses at both altitudes show rather greater net $\mathrm{O}_{3}$ production, due to a reduction in the destruction pathway $\mathrm{O}\left({ }^{1} D\right)+\mathrm{H}_{2} \mathrm{O}$ and to the subsequently lower $\mathrm{OH}$ concentrations reducing the rate of removal of $\mathrm{NO}_{x}$ to form $\mathrm{HNO}_{3}$. A dry air parcel at $300 \mathrm{hPa}$ containing $0.01 \%$ water by volume produces about $65 \mathrm{ppbv} \mathrm{O}_{3}$ in 10 days with the chemical initialization used, in contrast to the 50 parts per billion by volume (ppbv) produced in a relatively humid air mass with $0.25 \%$ water. The same variation in the water vapor content at $900 \mathrm{hPa}$ also leads to an additional $15 \mathrm{ppbv}$ of $\mathrm{O}_{3}$ production after 10 days, in this case moving from a net destruction into a net production regime. This shows the great sensitivity of photochemistry to the level of water vapor in an air parcel.

\section{Initial Concentrations}

In the previous two sensitivity studies, $300 \mathrm{hPa}$ isobaric trajectories were initialized with conditions more representative of surface concentrations, and the mixing processes affecting the air parcel during upward transport away from urban source areas were neglected. To assess the impact of different chemical initializations, heavily polluted urban conditions taken from the IPCC photochemistry intercomparison plume scenario [IPCC, 1995] were successively diluted by scaling with clean conditions representative of the marine boundary layer. These chemical conditions, shown in Table 3, were used to examine the effects of different chemical initializations on $\mathrm{O}_{3}$ production along the $300 \mathrm{hPa}$ isobaric trajectory. The water vapor concentration was fixed at $0.01 \%$ for all runs, appropriate to conditions at $300 \mathrm{hPa}$.

It is clear from Figure 4a that dilution of the polluted initial conditions leads to considerably reduced net $\mathrm{O}_{3}$ production. The rapid initial $\mathrm{O}_{3}$ production in the first 6 hours of the runs is primarily responsible for this. The total $\mathrm{O}_{3}$ production over the 10-day period falls

Table 3. Initial Concentrations Used for Studies Carried Out at $300 \mathrm{hPa}$ Considering the Impact of Chemical Initialization on Photochemical Ozone Production

\begin{tabular}{|c|c|c|c|c|c|c|c|c|}
\hline Plume & $\mathrm{O}_{3}$ & $\mathrm{CH}_{4}$ & $\mathrm{CO}$ & $\mathrm{H}_{2} \mathrm{O}_{2}$ & $\mathrm{NO}_{x}$ & $\mathrm{HNO}_{3}$ & $\mathrm{H}_{2} \mathrm{O}$ & NMHC \\
\hline Polluted & $50 \mathrm{ppb}$ & $1.7 \mathrm{ppm}$ & $600 \mathrm{ppb}$ & $2.0 \mathrm{ppb}$ & $10 \mathrm{ppb}$ & $100 \mathrm{ppt}$ & $0.01 \%$ & $300 \mathrm{ppbC}$ \\
\hline & $40 \mathrm{ppb}$ & $1.7 \mathrm{ppm}$ & $338 \mathrm{ppb}$ & $1.5 \mathrm{ppb}$ & $5 \mathrm{ppb}$ & $75 \mathrm{ppt}$ & $0.01 \%$ & $150 \mathrm{ppbC}$ \\
\hline $75 \%$ & $35 \mathrm{ppb}$ & $1.7 \mathrm{ppm}$ & $206 \mathrm{ppb}$ & $1.3 \mathrm{ppb}$ & 3 ppb & $63 \mathrm{ppt}$ & $0.01 \%$ & $75 \mathrm{ppbC}$ \\
\hline $90 \%$ & $32 \mathrm{ppb}$ & $1.7 \mathrm{ppm}$ & $128 \mathrm{ppb}$ & $1.1 \mathrm{ppb}$ & 1 ppb & $55 \mathrm{ppt}$ & $0.01 \%$ & $30 \mathrm{ppbC}$ \\
\hline $99 \%$ & $30 \mathrm{ppb}$ & $1.7 \mathrm{ppm}$ & $80 \mathrm{ppb}$ & $1.0 \mathrm{ppb}$ & $100 \mathrm{ppt}$ & $51 \mathrm{ppt}$ & $0.01 \%$ & $3 \mathrm{ppbC}$ \\
\hline Clean & $30 \mathrm{ppb}$ & $1.7 \mathrm{ppm}$ & $75 \mathrm{ppb}$ & $1.0 \mathrm{ppb}$ & $10 \mathrm{ppt}$ & $50 \mathrm{ppt}$ & $0.01 \%$ & $0 \mathrm{ppbC}$ \\
\hline
\end{tabular}


(a)

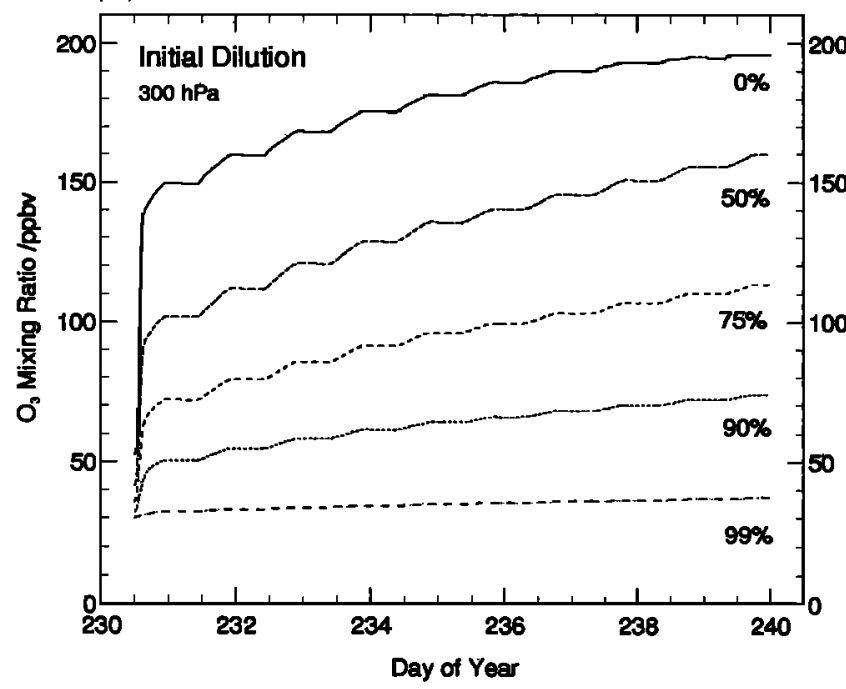

(b)

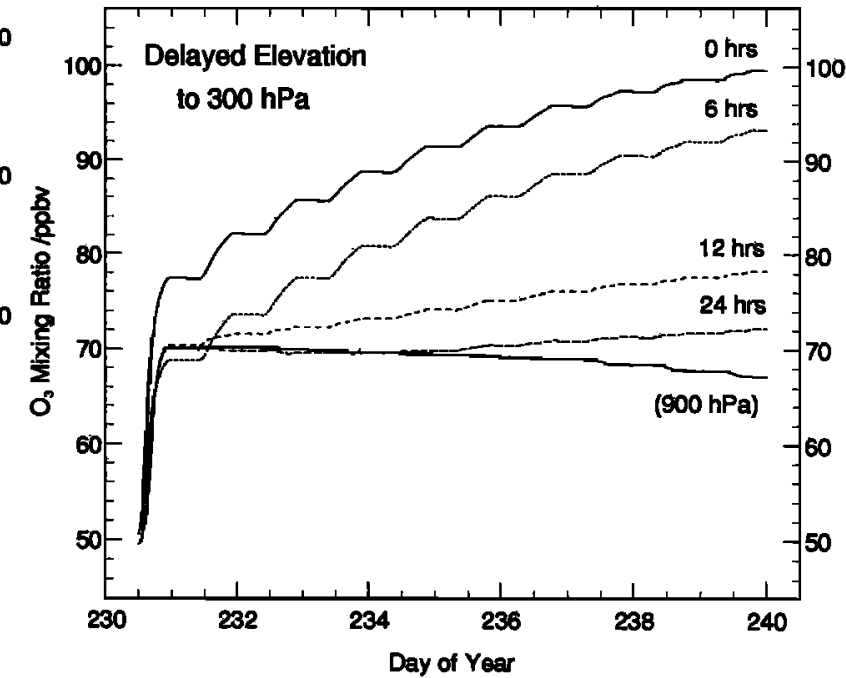

Figure 4. $\mathrm{O}_{3}$ production along 300 and $900-\mathrm{hPa}$ 10-day isobaric trajectories over the North Atlantic showing the effect of (a) diluting the initial concentrations with a proportion of clean background air and (b) varying the time of elevation to $300 \mathrm{hPa}$.

into two regimes; an initial jump in $\mathrm{O}_{3}$ levels due to the prescribed chemical conditions and then a slower formation for the remainder of the run. The initial jump is primarily due to rapid production of $\mathrm{O}_{3}$ from the $\mathrm{NO}_{x}$ cycle in the presence of high $\mathrm{RO}_{2}$ from oxidation of the short-lived hydrocarbons (e.g., alkenes), before $\mathrm{NO}_{x}$ is converted into $\mathrm{NO}_{y}$. Note that this initial production makes up an increasingly large proportion of the total production as $\mathrm{NO}_{x}$ levels are increased.

The initial $\mathrm{NMHC} / \mathrm{NO}_{x}$ ratio used in the present studies is large, about $30 \mathrm{ppbC} / \mathrm{ppb}$, and hence $\mathrm{O}_{3}$ production is limited by the quantity of $\mathrm{NO}_{x}$ available, as is the case in most regions of the atmosphere [McKeen et al., 1991; Chin et al., 1994]. Halving the initial $\mathrm{NO}_{x}$ levels leads to initial $\mathrm{O}_{3}$ production of only $58 \%$ of the polluted case, while doubling hydrocarbon levels increases the initial production by only $0.6 \%$, strong evidence for $\mathrm{NO}_{x}$ control.

The second stage involves slow production of $\mathrm{O}_{3}$ over the remaining 9 days. After the first day, $\mathrm{NO}_{x}$ levels are relatively low following oxidation to $\mathrm{HNO}_{3}$ and are buffered by $\mathrm{HNO}_{3}$ photolysis; the ratio of the $\mathrm{NO}_{x}$ species becomes an important factor in these conditions. The $\mathrm{NO} / \mathrm{NO}_{2}$ ratio is greatest for the $50 \%$ diluted plume, as NO removal by $\mathrm{RO}_{2}$ is lower than for the polluted plume, while the $\mathrm{OH} / \mathrm{HO}_{2}$ ratio is larger than for the more dilute plumes. Halving the initial $\mathrm{CO}$ concentration in the polluted plume does not affect the initial jump in $\mathrm{O}_{3}$ but leads to $50 \%$ greater $\mathrm{O}_{3}$ formation along the remainder of the trajectory, as the slower $\mathrm{OH}$ to $\mathrm{HO}_{2}$ conversion rate leads to to a greater $\mathrm{NO} / \mathrm{NO}_{2}$ ratio and hence to a greater $\mathrm{O}_{3}$ production efficiency. Note that rain-out of $\mathrm{HNO}_{3}$ and other soluble species has not been considered in these studies; removal of $\mathrm{NO}_{y}$ would lead to lower $\mathrm{NO}_{x}$ levels and hence reduced $\mathrm{O}_{3}$ production, and final $\mathrm{O}_{3}$ concentrations would therefore be more strongly controlled by the initial production than by production over the final 9 days.

\section{Delayed Elevation}

To assess the effects of the upward movement of an air mass, air parcels have been initialized at $900 \mathrm{hPa}$ and have been lifted to $300 \mathrm{hPa}$ over a 6-hour time step, completing the trajectory at $300 \mathrm{hPa}$. This elevation has been performed over the first, second, and fourth time steps, corresponding to the slow ascent of air over the respective 6-hour period. In practice, convective processes could lift an air parcel in as little as half an hour, but this sensitivity study serves to show how $\mathrm{O}_{3}$ production potential is affected by the timing of such elevation processes. The initial chemical conditions were the same as those from the first run; see Table 1.

The air parcels undergoing delayed elevation display a period of rapid $\mathrm{O}_{3}$ formation at low altitude, leading to greater removal of $\mathrm{NO}_{x}$, and therefore reduction in $\mathrm{O}_{3}$ production when the parcel reaches $300 \mathrm{hPa}$; see Figure 4b. This reduction in $\mathrm{NO}_{x}$ does not have sufficient time to occur in the parcel elevated during the first 6-hour period, and hence although the initial burst in $\mathrm{O}_{3}$ production is reduced with respect to the $300-\mathrm{hPa}$ air parcel, the $\mathrm{O}_{3}$ production efficiency for the remainder of the track is comparable. Longer periods of time spent at $900 \mathrm{hPa}$ before elevation subsequently lead to 
greatly reduced $\mathrm{O}_{3}$ formation rates at the higher altitude. The time between emission and elevation is therefore likely to provide a strong control on total photochemical $\mathrm{O}_{3}$ production from urban plumes, similar to the effect described by Chatfield and Delaney [1990] for biomass burning plumes.

\section{Further Considerations}

The main conclusions from these studies is that the $\mathrm{O}_{3}$ production efficiency in the upper troposphere is considerably greater than that in the lower troposphere. This has also been found by Pickering et al. [1990, 1991] in studies of convection and indicates that the potential for long-range transport of secondary pollutants from North America to Europe is considerably greater at higher altitudes. This effect is enhanced by the shorter transport times that are typical of higheraltitude transport. At both 300 and $900 \mathrm{hPa}$ a reduction in water vapor content leads to increased $\mathrm{O}_{3}$ production. Studies with a variety of initial concentrations have indicated that considerable photochemical $\mathrm{O}_{3}$ formation is still possible from rather less polluted starting conditions. The initial rapid $\mathrm{O}_{3}$ production due to oxidation of the highly reactive hydrocarbons becomes successively less important for cleaner air parcels, and $\mathrm{O}_{3}$ formation along the remainder of the trajectory becomes more critical.

To what extent is the $\mathrm{O}_{3}$ production seen here observed in the atmosphere? In these studies, $\mathrm{O}_{3}$ production is enhanced by the buffering effect of $\mathrm{HNO}_{3}$ formation and photolysis on $\mathrm{NO}_{x}$ levels. However, the lack of removal of $\mathrm{NO}_{y}$ by rain-out or dilution maintains $\mathrm{NO}_{x}$ concentrations at artificially high levels, considerably enhancing $\mathrm{O}_{3}$ production. In reality, the high levels of $\mathrm{HNO}_{3}$ and $\mathrm{NMHCs}$ would be diluted as the air parcel mixes with the surrounding air and would at some point drop below the critical concentration required to keep $\mathrm{NO}_{x}$ levels above the $\mathrm{O}_{3}$ formation threshold [Milford et al., 1994]. Mixing processes will therefore affect the $\mathrm{O}_{3}$ production efficiency of the air as well as directly affecting the concentrations of all the constituent gases. Similarly, removal of $\mathrm{NO}_{y}$ and $\mathrm{H}_{2} \mathrm{O}_{2}$ in the aqueous phase by rain-out is liable to reduce the $\mathrm{O}_{3}$ production potential. To examine a more physically realistic scenario, a case study has been performed for crossAtlantic transport considering these physical processes in more detail.

\section{Cross-Atlantic Trajectories: A Case Study}

The NCAR King Air aircraft made a number of flights off the northeastern coast of the United States in late August 1993 as part of the NARE intensive [ $B u h r$ et al., this issue]. On several of these flights, polluted plumes were intercepted moving out over the ocean from the New York/Boston area in a northeasterly direction.
In particular, a plume was detected above the marine boundary layer over the Gulf of Maine at an altitude of about $1 \mathrm{~km}$ on August 20, 4 days before the first flight of the Meteorological Research Flight Hercules in the OCTA campaign on the European side of the Atlantic.

To assess the possible destination of these plumes, forward trajectories were calculated for the second half of August from the coast of North America. Analyzed wind fields were obtained from the ECMWF global weather forecast model, which was run for the August 1993 period constrained with observed meteorological parameters. Three-dimensional forward trajectories were calculated using the TOPCAT trajectory calculation package, based on the Toulouse Off-Line 3-D Model of Chemistry and Transport (TOMCAT) [Chipperfield et al., 1993]. The trajectory package uses T106 (approximately $1^{\circ} \times 1^{\circ}$ ) resolution at 31 altitude levels with a 6 -hour time resolution.

Trajectories were initialized at $50-\mathrm{hPa}$ intervals and run for a period of 10 days from the Gulf of Maine. Five trajectories were initialized at each altitude, using the method of Merrill et al. [1989], with a point over the center of the intercepted plume and four points in a square of side $1^{\circ}$ around it. This approach allows the diffluence of trajectories to be determined and may reveal the presence of meteorological boundaries. Forward trajectories calculated for the plume intercepted by the King Air on August 20 over the Gulf of Maine are shown in Figure 5; note that for clarity, only the central trajectory at each altitude is shown.

Below $850 \mathrm{hPa}$ the trajectories typically headed south along the coast and returned to the southeastern United
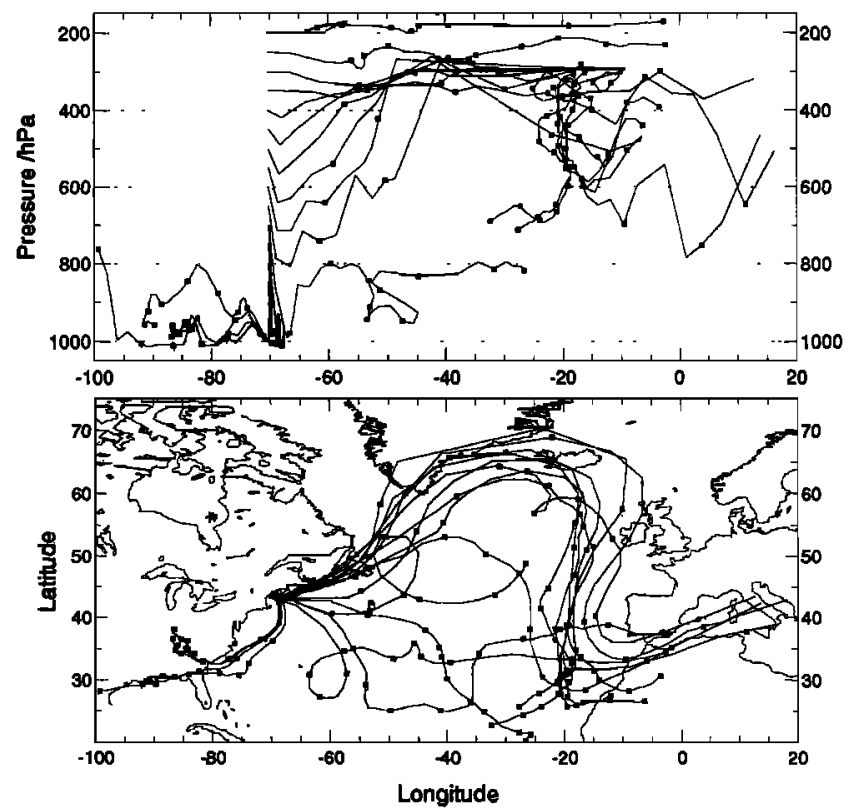

Figure 5. Ten-day forward trajectories calculated from the region of the plume intercepted by the King Air on August 20. For clarity, only one trajectory is plotted at each altitude; the positions are plotted every 6 hours and markers indicate 24-hour intervals, 
(a)

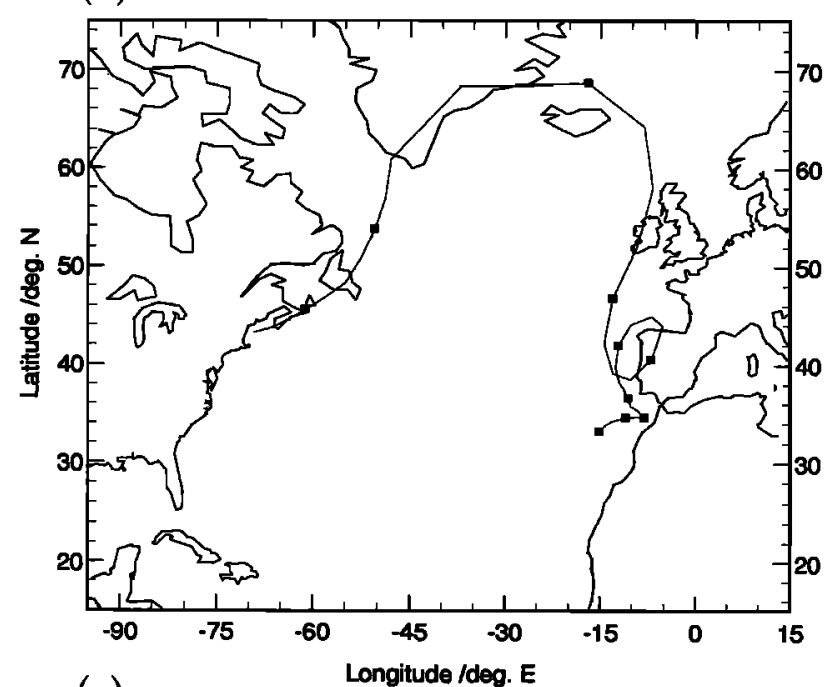

(c)

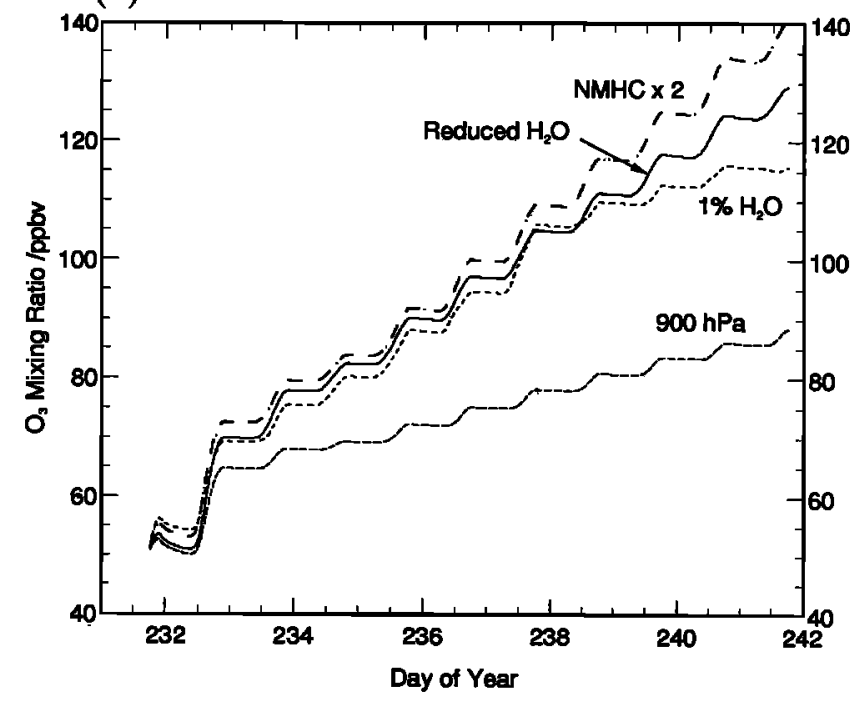

(b)

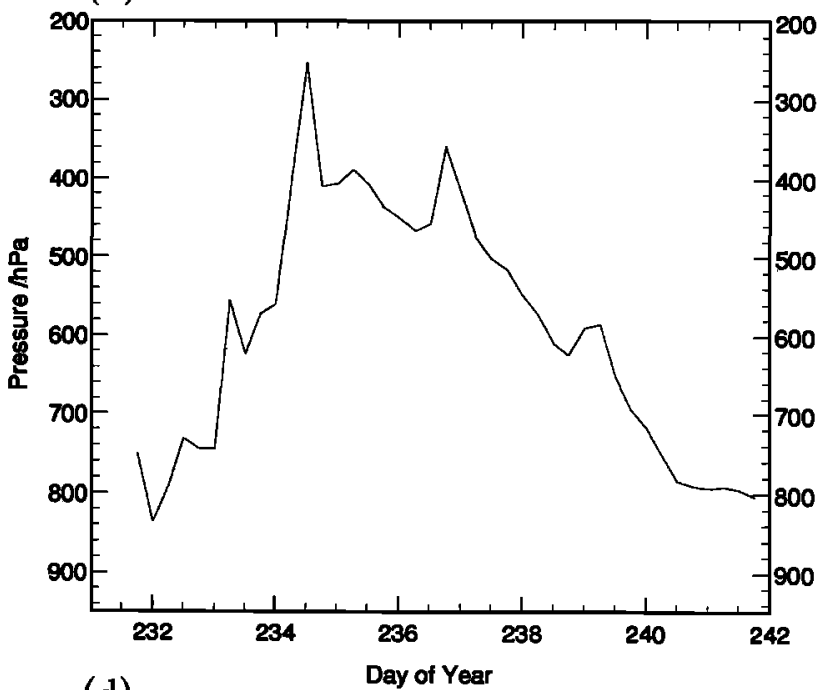

(d)

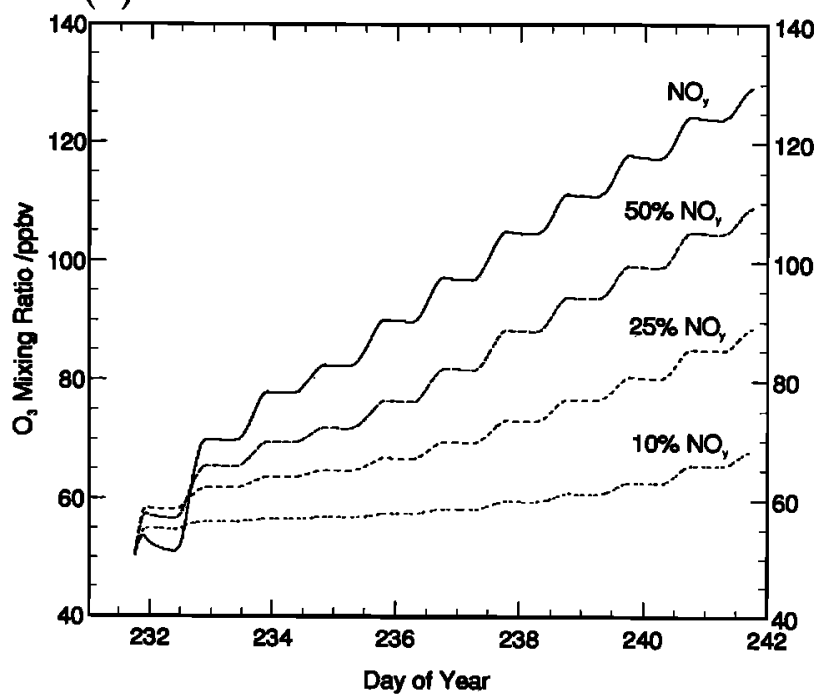

Figure 6. A 10-day trajectory over the North Atlantic ending on August 31, showing (a) the trajectory path and (b) altitude and the effects on $\mathrm{O}_{3}$ production of varying (c) water vapor and non-methane hydrocarbon mixing ratio, and (d) the initial proportions of $\mathrm{NO}_{y}$ relative to the standard of 15 ppbv.

States. Above this level, the air moved northeastward and upward, was caught up in the high-pressure system over the North Atlantic, and then transported rapidly to the eastern shores of the Atlantic. The plume intercepted by the King Air consisted of polluted layers between 800 and $975 \mathrm{hPa}$, and hence some of the more elevated layers may have been lifted up around the North Atlantic high-pressure system and transported across the Atlantic. Several of the trajectories arrive within 7 days on the eastern side of the Atlantic at altitudes below $6 \mathrm{~km}$.

A 10-day trajectory starting over the Gulf of Maine at $750 \mathrm{hPa}$ was selected, describing an air mass moving slowly toward Nova Scotia and dropping down to $840 \mathrm{hPa}$ in the region of the plume before rising and moving rapidly around the mid-Atlantic high; see Figures $6 \mathrm{a}$ and $6 \mathrm{~b}$. After briefly reaching a maximum level of $260 \mathrm{hPa}$, in the region of the tropopause, the trajectory descends slowly as the air mass moves southward, dropping from $400 \mathrm{hPa}$ over the western coast of Ireland to $800 \mathrm{hPa}$ off the coast of Morocco, only rising briefly when looping over the coast of Spain. Note that transport across the Atlantic as far as the British Isles takes only 3.5 days. This trajectory was initialized at $1800 \mathrm{UT}$; note that the plume interception occurred at about 1530 UT.

This cross-Atlantic trajectory was initialized with measurements made by the King Air in the plume on August 20 [Buhr et al., this issue]. Values close to the maximum concentrations in the plume have been selected for the present studies and are given in Table 4. The most polluted of the sample bottles was used to initialize the hydrocarbon species. Note that this did not coincide with the center of the plume due 
Table 4. Initial Concentrations Based on in-Plume Measurements Made by the King Air Aircraft Over the Gulf of Maine on August 20

\begin{tabular}{ccccccc}
\hline \hline $\mathrm{O}_{3}$ & $\mathrm{CH}_{4}$ & $\mathrm{CO}$ & $\mathrm{H}_{2} \mathrm{O}_{2}$ & $\mathrm{NO}$ & $\mathrm{NO}_{y}$ & $\mathrm{H}_{2} \mathrm{O}$ \\
\hline $50 \mathrm{ppbv}$ & $1.7 \mathrm{ppmv}$ & $240 \mathrm{ppbv}$ & $2.0 \mathrm{ppbv}$ & $1.0 \mathrm{ppbv}$ & $15 \mathrm{ppbv}$ & - \\
\hline $\mathrm{C}_{2} \mathrm{H}_{6}$ & $\mathrm{C}_{3} \mathrm{H}_{8}$ & $\mathrm{C}_{4} \mathrm{H}_{10}$ & $\mathrm{C}_{5} \mathrm{H}_{12}$ & $\mathrm{C}_{2} \mathrm{H}_{4}$ & $\mathrm{C}_{3} \mathrm{H}_{6}$ & $\mathrm{C}_{2} \mathrm{H}_{2}$ \\
\hline $1500 \mathrm{pptv}$ & $1500 \mathrm{pptv}$ & $900 \mathrm{pptv}$ & $1000 \mathrm{pptv}$ & $600 \mathrm{pptv}$ & $120 \mathrm{pptv}$ & $800 \mathrm{pptv}$ \\
\hline \hline
\end{tabular}

to the finite sampling time (about $8 \mathrm{~min}$ ), and therefore the total NMHC concentration of about $19.3 \mathrm{ppbC}$ is likely to be considerably lower than the in-plume maximum. Measurements for aromatic species and oxygenated species such as the aldehydes are also unavailable. The $\mathrm{NMHC} / \mathrm{NO}_{x}$ ratio is therefore about 4 , slightly lower than the 5-20 typical of recently polluted air [Seinfeld, 1989]. In the following studies, the water vapor volume mixing ratio has been taken from the U.S. Standard Atmosphere (1976), reduced as the trajectory rises in altitude, but not considering any reevaporation of condensed water, so that the water vapor remains at the mixing ratio appropriate for the highest altitude achieved by the trajectory $(0.001 \%$ after the highest point at $250 \mathrm{hPa}$ ) and there is no remoistening on descent. In reality, removal of water vapor above the saturation point is liable to lead to formation of water or ice and therefore heterogeneous removal of species such as $\mathrm{HNO}_{3}$; this has not been considered in the present study. The temperature has been taken from the ECMWF analyses and varies along the trajectory.

\section{Chemical Influences}

The chemical initialization used for these runs leads to much greater $\mathrm{O}_{3}$ production than in the sensitivity studies; see Figure $6 \mathrm{c}$. This is principally due to a plume $\mathrm{NO}_{y}$ mixing ratio of $15.0 \mathrm{ppbv}$ in contrast to the $2.1 \mathrm{ppbv}$ in the sensitivity studies; note that the total NMHC loading is only half as much. The initial burst of NMHC oxidation seen in the sensitivity studies is not seen here due to the lower $\mathrm{NMHC} / \mathrm{NO}_{\boldsymbol{x}}$ ratio. Note that the $\mathrm{NO}$ and $\mathrm{NO}_{y}$ mixing ratios were measured on the King Air but that $\mathrm{NO}_{2}$ mixing ratios were not available. In the standard scenario it has been assumed that the $\mathrm{NO} / \mathrm{NO}_{2}$ ratio is 0.25 and that the remaining $10 \mathrm{ppbv}$ is $\mathrm{HNO}_{3}$. Photochemical steady state predicts an $\mathrm{NO} / \mathrm{NO}_{2}$ ratio of about 0.65 in these conditions; using $1.5 \mathrm{ppbv}$ of $\mathrm{NO}_{2}$ and the remainder as $\mathrm{HNO}_{3}$ leads to an enhancement of $5 \mathrm{ppbv}$ of $\mathrm{O}_{3}$ over the standard run on the first day but is within $1 \mathrm{ppbv}$ for the rest of the trajectory.

The impact of reducing the water vapor content can be seen by comparing the run with one using a constant water vapor mixing ratio of $1 \%$; see Figure $6 c$. Note that the difference in the $\mathrm{O}_{3}$ production potential is only evident after about 7 days. The reduced water vapor leads to lower $\mathrm{OH}$ concentrations from the $\mathrm{O}\left({ }^{1} D\right)+\mathrm{H}_{2} \mathrm{O}$ reaction, which reduce the rate of conversion of $\mathrm{NO}_{x}$ into $\mathrm{HNO}_{3} . \mathrm{NO}_{x}$ levels are therefore higher in the reduced water runs, averaging $450 \mathrm{pptv}$ for the last 5 days rather than 300 pptv. The higher NO concentrations lead to a large reduction in the concentrations of peroxy radicals, with a daytime maximum of 6 pptv by the fifth day rather than 35 pptv, and hence to reduced $\mathrm{O}_{3}$ production efficiency from the $\mathrm{NO}_{x}$ cycle per unit $\mathrm{NO}_{x}$. However, the greater total $\mathrm{NO}_{x}$ concentration offsets this, and the total $\mathrm{O}_{3}$ production is very similar for the first 7 days in both runs. After 10 days the $1 \%$ water scenario shows little additional $\mathrm{O}_{3}$ production, but the reduced water run shows twice as much $\mathrm{NO}_{x}$ and $50 \%$ greater hydrocarbon levels due to the lower $\mathrm{OH}$ concentrations, and hence $\mathrm{O}_{3}$ production continues to occur. Decreasing water vapor may therefore reduce $\mathrm{O}_{3}$ production efficiency per unit $\mathrm{NO}_{x}$ while increasing total $\mathrm{O}_{3}$ production.

The effect on $\mathrm{O}_{3}$ levels of doubling the total initial NMHC concentration is also shown in Figure 6c. After 10 days there is a relatively small enhancement in $\mathrm{O}_{3}$ of $11 \mathrm{ppbv}$, indicating that $\mathrm{O}_{3}$ production is principally under $\mathrm{NO}_{x}$ control, as in the sensitivity studies. The effect of reducing the total initial $\mathrm{NO}_{y}$ is shown in Figure $6 \mathrm{~d}$. Net $\mathrm{O}_{3}$ production is seen in all the runs, even with a total $\mathrm{NO}_{y}$ mixing ratio of only $1.5 \mathrm{ppbv} . \mathrm{O}_{3}$ production is enhanced toward the end of these runs, where the trajectory is descending, as $\mathrm{NO}_{x}$ levels increase. This is due to the return of $\mathrm{NO}_{x}$ by thermal degradation of peroxyacetyl nitrate (PAN) and, to a lesser extent, $\mathrm{HNO}_{4}$, which sequester $\mathrm{NO}_{2}$ in the cold conditions in the upper troposphere. Note that this effect is more significant for low $\mathrm{NO}_{x}$ conditions, where $\mathrm{O}_{3}$ production efficiency per unit $\mathrm{NO}_{x}$ is greater and hence where the extra source of $\mathrm{NO}_{x}$ has a larger impact.

\section{Physical Influences}

Runs have been performed to assess the importance of physical processes in affecting the composition of air masses. The following studies focus principally on mixing processes; it has been assumed that the air mass is below the saturation point, and therefore wet deposition processes have not been considered. If condensation had occurred, wet deposition would be expected 
Table 5. Background Chemical Conditions Used for Diluting Cross-Atlantic Trajectories (Expressed in Volume Mixing Ratio)

\begin{tabular}{ccccc}
\hline $\mathrm{O}_{3}$ & $\mathrm{CO}$ & $\mathrm{H}_{2} \mathrm{O}_{2}$ & $\mathrm{HNO}_{3}$ & $\mathrm{NMHC}$ \\
\hline U.S. profile & $75 \mathrm{ppbv}$ & $0.5 \mathrm{ppbv}$ & $100 \mathrm{pptv}$ & $3.0 \mathrm{ppbC}$ \\
\hline
\end{tabular}

to lead to significant additional removal of $\mathrm{O}_{3}$ precursors. The effect of altitude is highlighted in an isobaric run at $900 \mathrm{hPa}$ along the same latitudinal path using the same fixed temperature $(273 \mathrm{~K})$ and water vapor mixing ratio $(0.25 \%)$ as for the sensitivity studies; see Figure $6 \mathrm{c}$. There is slow $\mathrm{O}_{3}$ production along the trajectory during the daytime, when the peak $\mathrm{NO}_{x}$ levels reach almost 250 pptv, maintained by photolysis of $\mathrm{HNO}_{3}$. This lower $\mathrm{O}_{3}$ production capacity at the lower altitude is the same effect as that seen in the sensitivity studies, except that the greater total $\mathrm{NO}_{y}$ used (15 ppbv rather than $2.1 \mathrm{ppbv}$ ) is sufficient to maintain an $\mathrm{O}_{3}$ production regime.

To simulate the effect of turbulent diffusion mixing the air parcel with adjacent air masses, background concentrations were provided for the long-lived species; see Table 5. These concentrations were slowly mixed into the air parcel using a modified dispersion equation applicable for plume dilution from a chimney stack and assuming no diffusion in the direction of motion [Cocks and Fletcher, 1982]:

$$
\frac{d C_{i}}{d t}=\left(\frac{d C_{i}}{d t}\right)_{\text {chem }}+\frac{2\left(C_{i}^{\prime}-C_{i}\right)}{t+t_{\mathrm{o}}}
$$

where $C_{i}$ and $C_{i}^{\prime}$ are the plume and background concentrations of species $i$ at time $t$, respectively. The time constant $t_{\mathrm{o}}$ is given by $R / W \tan \theta$, where $R$ is the plume radius, $W$ is the effective wind speed, and $\theta$ is half the planar vertex angle of the plume. In the present study, the plume has been assumed to be large, appropriate for an extended source region, and hence $t_{\mathrm{o}}$ has been taken as constant at 1 day. This is a fairly crude treatment but allows the magnitude of the effects of dilution to be assessed. In practice, use of this time constant leads to rather rapid dilution, and hence in subsequent runs the dilution term in the equation was halved to consider a "slow dilution" scenario to contrast with the standard "rapid dilution" case.

In a "tropospheric" scenario, background $\mathrm{O}_{3}$ concentrations for the appropriate altitude were taken from the profile given in the U.S. Standard Atmosphere (1976). In a "stratospheric" scenario, $\mathrm{O}_{3}$ concentrations were taken from about $1.5 \mathrm{~km}$ higher in altitude than the trajectory, leading to the stepped profile shown in Figure 7b. The difference in the background $\mathrm{O}_{3}$ levels between these two scenarios is relatively small below $500 \mathrm{hPa}$; the greatest difference occurs above $400 \mathrm{hPa}$, where the "stratospheric" scenario simulates an environment rich in stratospheric $\mathrm{O}_{3}$ following intrusion of stratospheric air into the upper troposphere.

All runs involving dilution show considerably reduced $\mathrm{O}_{3}$ concentrations after 10 days; see Figure 7a. For the slower dilution rate with tropospheric air, photochemical production and dilution are evenly matched, and (a)

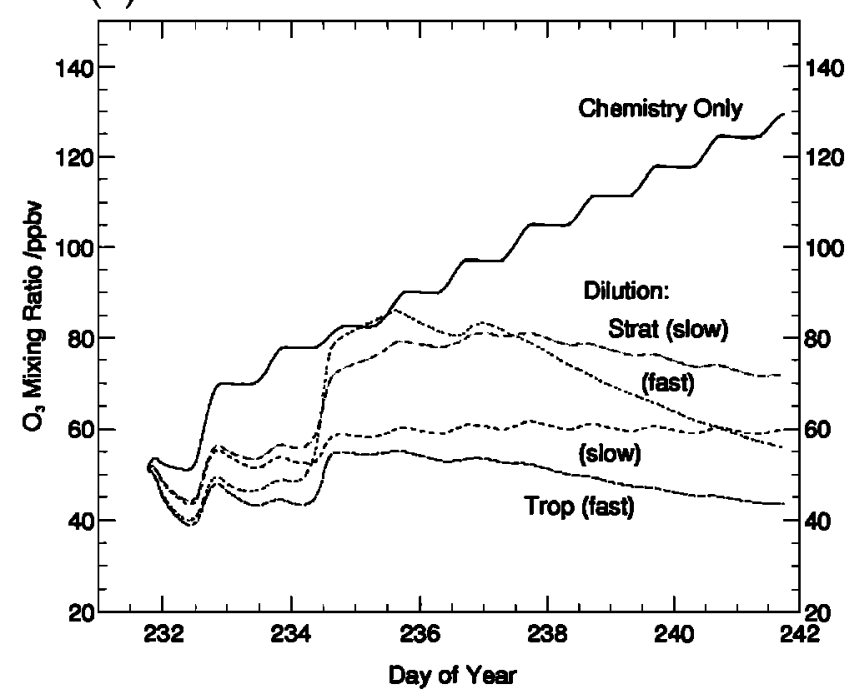

(b)

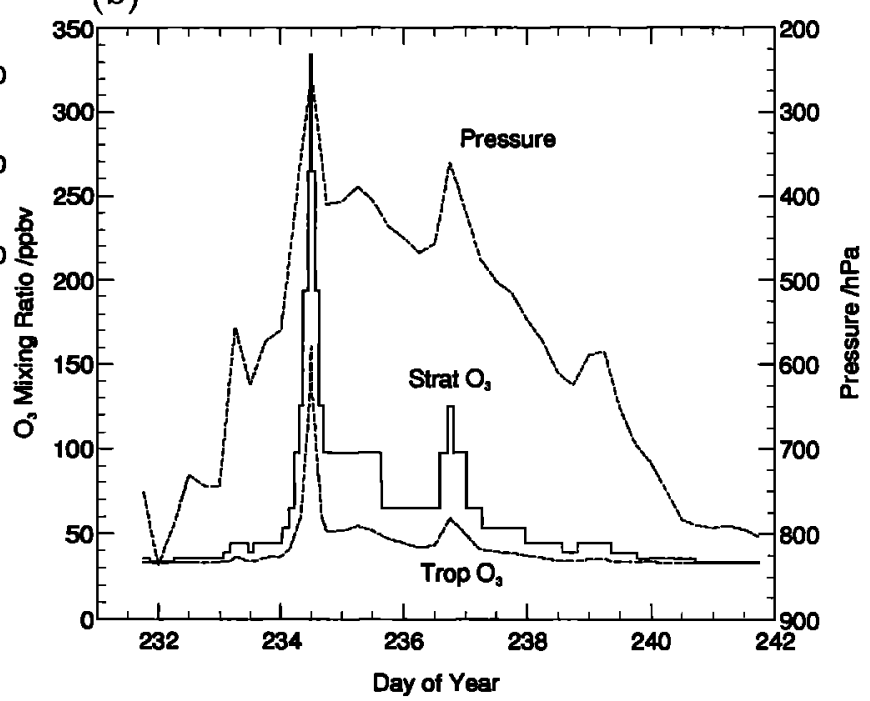

Figure 7. (a) The effect on $\mathrm{O}_{3}$ production of including a parameterization of the dilution of the air parcel using background concentrations representing tropospheric ("trop") or stratospheric ("strat") air, with two different mixing rates. (b) The $\mathrm{O}_{3}$ mixing ratios representing background air derived from the U.S. Standard Atmosphere (1976). 
$\mathrm{O}_{3}$ levels are maintained; using a faster dilution rate or stratospheric background air leads to net $\mathrm{O}_{3}$ loss after the first 4 days of the trajectory. Close to the source regions, where the air parcel contains higher levels of pollutants, dilution reduces the photochemical $\mathrm{O}_{3}$ production rate; $\mathrm{O}_{3}$ production on the second day of the trajectory is reduced from $19 \mathrm{ppbv}$ with no dilution to $12 \mathrm{ppbv}$ with slow dilution and $9 \mathrm{ppbv}$ with rapid dilution. At higher altitudes, where the difference between the "tropospheric" and "stratospheric" scenarios becomes more significant, dilution contributes more to the increase in $\mathrm{O}_{3}$ than photochemical processes. On the fourth day (day 234), when the parcel briefly rises to $250 \mathrm{hPa}$, photochemical production of $\mathrm{O}_{3}$ on the chemistry-only run leads to an enhancement of about 4 ppbv; slow and rapid dilution with tropospheric air leads to enhancements of 6 and $9 \mathrm{ppbv}$ and with stratospheric air enhancements of 18 and $30 \mathrm{ppbv}$, respectively. Note that rapid dilution with stratospheric air leads to higher levels of $\mathrm{O}_{3}$ than in the chemistry-only scenario. When the air parcel returns to the lower troposphere, $\mathrm{O}_{3}$ levels again become more dependent on the dilution rate than on the difference in the background conditions.

To attempt to decouple the effects on $\mathrm{O}_{3}$ levels of the dilution of the air parcel from that of photochemistry, the trajectory was followed without chemistry, allowing the background $\mathrm{O}_{3}$ values to diffuse into the air mass at the same rates as before. Comparisons of the chemistry only, chemistry and dilution, and dilution-only scenarios are shown for stratospheric background air with slow and rapid dilution rates (Figures $8 \mathrm{a}$ and $8 \mathrm{~b}$, respectively). In the slower dilution scenario, photochemical production of $\mathrm{O}_{3}$ is significant on the first day, producing an enhancement of $12 \mathrm{ppbv}$, but in the following 9 days the additional enhancement is only 3 ppbv. In the rapid dilution scenario the initial 9 ppbv enhance-

\section{(a)}

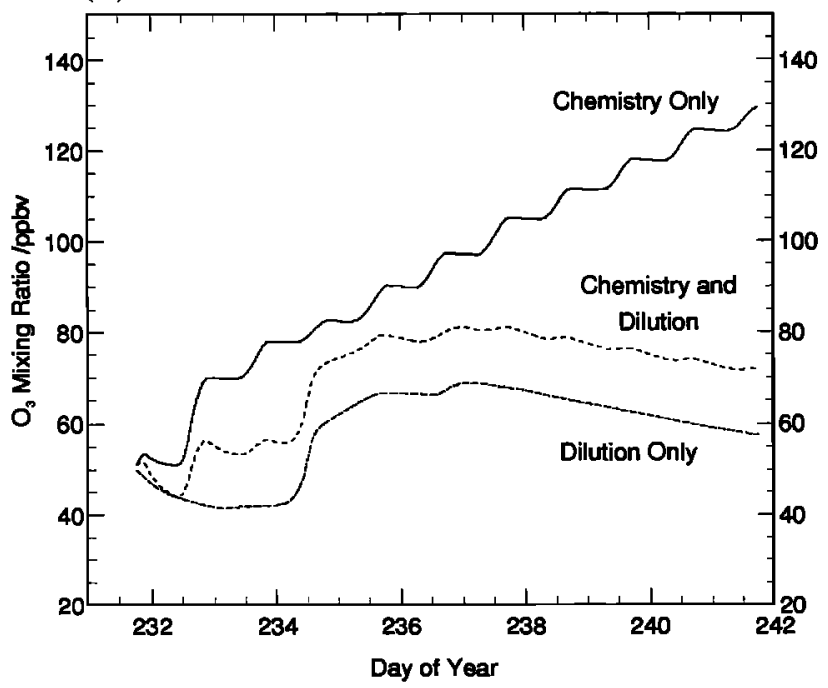

ment is eroded, and the total enhancement due to photochemistry by the end of the run is only $2 \mathrm{ppbv}$. The slower mixing rate allows photochemistry to have a significant impact on final $\mathrm{O}_{3}$ levels in the air parcel, while this effect is removed with more rapid mixing; the balance between photochemistry and dilution in determining final $\mathrm{O}_{3}$ concentrations is therefore highly dependent on the mixing rate.

Clearly, mixing processes play a major role in determining the $\mathrm{O}_{3}$ levels calculated along trajectories of this length. The parameterization of the mixing process used in these studies is greatly simplified; it has not been possible to come up with anything other than an ad hoc estimate of the dilution rate, which has been assumed not to vary over the course of the trajectory. Note that concentrations in background air for gases other than $\mathrm{O}_{3}$ have not been varied with altitude and that the "stratospheric" concentrations use elevated $\mathrm{O}_{3}$ levels but not elevated levels of $\mathrm{NO}_{y}$ which might be expected to contribute to $\mathrm{O}_{3}$ production in the troposphere. In practice, the impact of mixing will depend on both the meteorological conditions and on the background chemical conditions that the air mass interacts with. Ideally, this type of study should be carried out in conjunction with a regional model, including a full treatment of the meteorological conditions.

\section{Conclusions From Cross-Atlantic Trajectories}

The chemical studies with cross-Atlantic trajectories indicate that photochemical $\mathrm{O}_{3}$ production on crossAtlantic trajectories is principally $\mathrm{NO}_{x}$ limited and that in the absence of physical removal of $\mathrm{NO}_{y}$ species this is controlled by the $\mathrm{NO}_{x}$ buffering effect of $\mathrm{HNO}_{3}$ formation and destruction. Reduction in $\mathrm{NO}_{x}$ following dilution or deposition of $\mathrm{NO}_{y}$ or by formation of longerlived reservoir species such as $\mathrm{PAN}$ or $\mathrm{HNO}_{4}$ reduces the capacity for $\mathrm{O}_{3}$ formation, although return of $\mathrm{NO}_{x}$ from

(b)

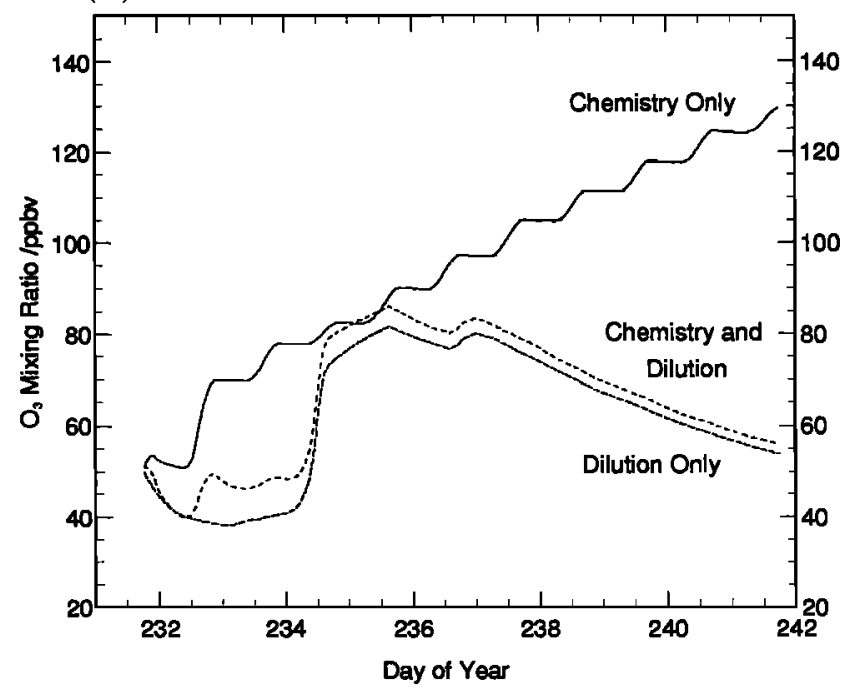

Figure 8. The relative effects on $\mathrm{O}_{3}$ production of photochemistry and dilution with "stratospheric" air using (a) the slow dilution rate and (b) the rapid dilution rate. 
the reservoir species may lead to greater $\mathrm{O}_{3}$ production on returning to warmer conditions. The initial $\mathrm{NO}_{y}$ speciation influences $\mathrm{O}_{3}$ production relatively close to the source regions, but total $\mathrm{NO}_{y}$ levels control any subsequent production.

These studies show that mixing processes play a major part in controlling the $\mathrm{O}_{3}$ concentrations more than 5 days along the trajectory and in limiting the initial photochemical $\mathrm{O}_{3}$ production. To assess the relative impact of these processes on trace gas distributions off the coast of Europe, atmospheric measurements taken at the end of the trajectories near the coast of Portugal have been considered.

\section{Aircraft Measurements During OCTA}

Measurements of trace gas species were taken by the MRF C-130 Hercules research aircraft over the Atlantic between August 24 and September 1, 1993, as part of the OCTA campaign [Volz-Thomas et al., 1994]. The data collected on flight profiles during the last few days of August along the western coast of the European continent reveal a significant degree of horizontal layering. This is particularly clear on flight A272 out of Rabat, Morocco, on August 31, where profiles taken off the coast of Portugal showed considerable stratification and apparently elevated levels of pollutants in the midtroposphere well above the boundary layer. As an example, data from one of the profiles, the "Lisbon profile" at $39^{\circ} \mathrm{N}, 11.25^{\circ} \mathrm{W}$, about $150 \mathrm{~km}$ off the coast of Portugal, are shown in Figure 9.

The surface layer, $50-100 \mathrm{~m}$ deep, is evident at the bottom of the profile, with water vapor approaching $2 \%$ by volume and $\mathrm{H}_{2} \mathrm{O}_{2}$ depleted by deposition to the ocean surface. Above this is a shallow layer of about a 500-m depth showing rather variable $\mathrm{O}_{3}$ concentrations and with $\mathrm{H}_{2} \mathrm{O}_{2}$ levels increasing with distance from the surface. The deep, relatively well mixed marine boundary layer stretches up to about $2400 \mathrm{~m}$, with uniformly high water vapor and aerosol concentrations. Elevated levels of $\mathrm{NO}_{y}$ and $\mathrm{CO}$ are also apparent, suggesting that this layer contains air which has recently passed over continental Europe. Variations in $\mathrm{O}_{3}, \mathrm{NO}_{y}$, and $\mathrm{CO}$ indicate the existence of a number of distinct sublayers, also visible in flight profiles taken farther south. A dry layer between $2.5 \mathrm{~km}$ and $3.0 \mathrm{~km}$ caps this remnant boundary layer, with a water vapor mixing ratio reduced to about $0.03 \%$. This layer contains lower levels of $\mathrm{O}_{3}, \mathrm{H}_{2} \mathrm{O}_{2}, \mathrm{CO}$, and particulate matter, indicating a relatively clean air mass, probably of midtropospheric origin. Between 3.0 and $4.6 \mathrm{~km}$ there are a number of rather thinner layers with varying quantities of $\mathrm{O}_{3}$ and $\mathrm{H}_{2} \mathrm{O}_{2}$; in particular, the thin layer just above $3.0 \mathrm{~km}$ shows elevated levels of $\mathrm{O}_{3}$ and $\mathrm{H}_{2} \mathrm{O}_{2}$ accompanied by a significant increase in water vapor.

Above $4.6 \mathrm{~km}$ the concentration of $\mathrm{O}_{3}$ increases slowly to the top of the profile by about $17 \mathrm{ppbv}$, with simultaneous increases of $25 \mathrm{ppbv}$ in $\mathrm{CO}, 250 \mathrm{pptv}$ in $\mathrm{NO}_{y}$, and a doubling of aerosol loading suggesting an anthropogenic source. The water vapor content increases above $5.6 \mathrm{~km}$ but is still relatively low, about $0.1 \%$, indicating that the air has not recently been close to the surface. However, this is not sufficiently dry to suggest stratospheric influence. The aircraft does not emerge from the top of this region, so it is not clear whether this composition is typical of the upper troposphere in this region at the time, or whether it is a unique layer.

\section{Back Trajectories}

To assess the origins of the air masses intercepted on the Lisbon profile, 10-day back trajectories have been calculated for points in the region of the profile at 50$\mathrm{hPa}$ intervals with the same technique used for the forward trajectories. Trajectories arriving off the coast of Portugal at noon on August 31 are shown in Figures 10a-10c. Note the general similarity in the midtroposphere with the 10-day forward trajectories calculated from the Gulf of Maine 11 days earlier, shown in Figure 5.

Trajectories arriving below $700 \mathrm{hPa}$, about $2.6 \mathrm{~km}$, originate from the North Sea, passing in a narrow channel between the Atlantic high-pressure ridge and the low-pressure systems over Europe; see Figure 10a. The trajectories pass through the boundary layer over continental Europe before rising over the northern Pyrenees and fanning out to all altitudes between $700 \mathrm{hPa}$ and $1000 \mathrm{hPa}$. Before arriving over the North Sea, roughly equal numbers of trajectories originate from north of Russia below $800 \mathrm{hPa}$ and from the North Atlantic, either below $800 \mathrm{hPa}$ over Iceland or from around $400 \mathrm{hPa}$ over Greenland.

Between 600 and $700 \mathrm{hPa}$ the wind veers round from being northeasterly to being predominantly from the west; see Figure 10b. At these altitudes there is a period of stagnation around the profile point lasting about 2 days, before which roughly equal numbers of trajectories originate from the lower troposphere in the northeast and from the midtroposphere in the west. Trajectories arriving above $600 \mathrm{hPa}$, about $3.7 \mathrm{~km}$, originate from the midtroposphere in the west; see Figure 10c. Those arriving at $500 \mathrm{hPa}$, about $5.0 \mathrm{~km}$, have taken 4 or 5 days from the Azores in a slow eastward moving air mass. Prior to this stagnation the air may either have originated from around the mid-Atlantic high or from eastern North America before moving around the North Atlantic high, providing the possibility of anthropogenic influence. Note that this period of stagnation over the eastern Atlantic is also visible in the forward trajectories, Figure 5, starting about August 27.

Above $300 \mathrm{hPa}$, about $8.6 \mathrm{~km}$, the air originates from the west, bringing air increasingly greater distances from over the Pacific Coast of North America and beyond. This air appears to have little influence on lower levels in the troposphere and, in the absence of significant convective uplift, is likely to play a relatively small 

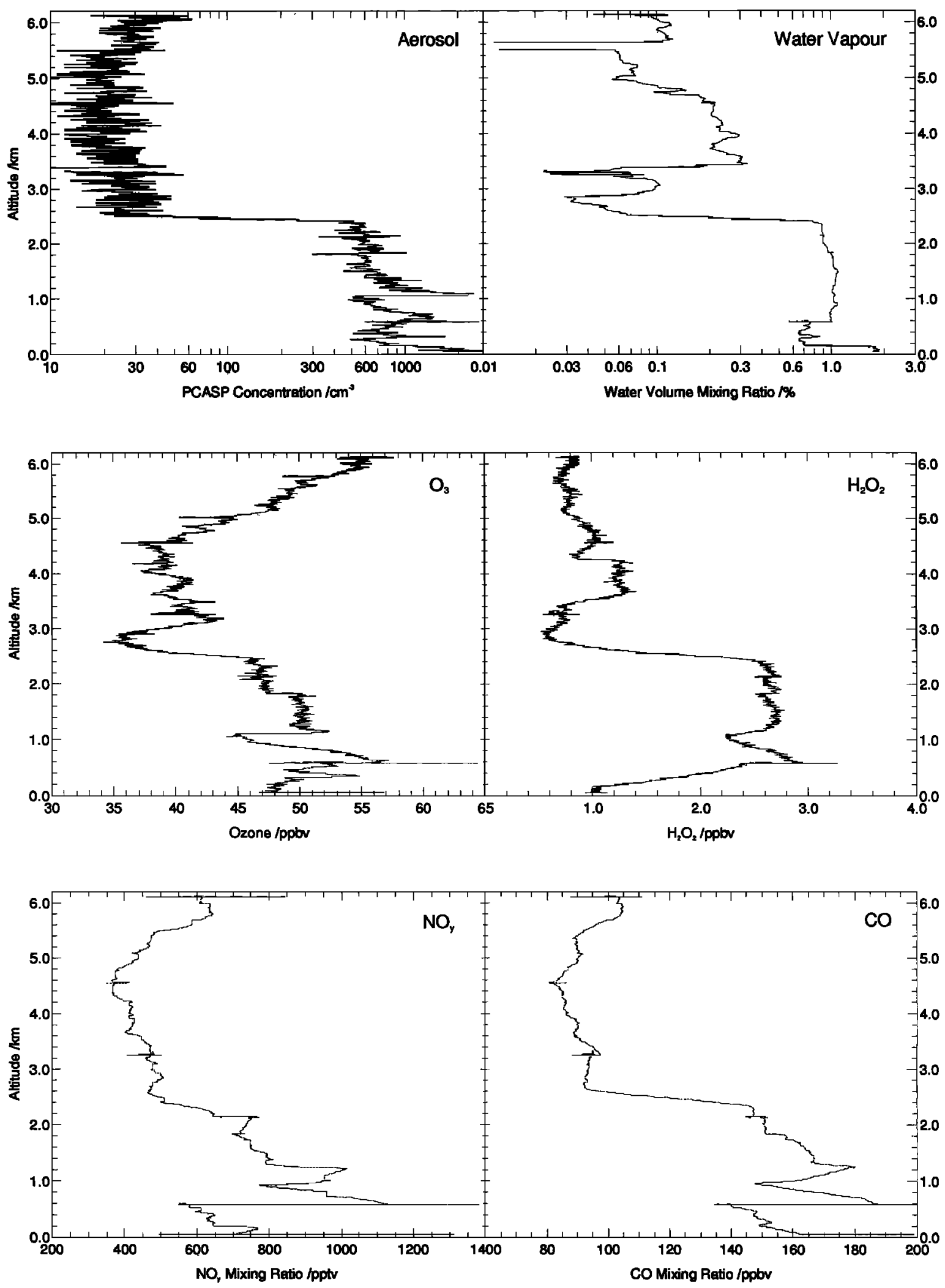

Figure 9. Vertical profiles of a number of species taken off the coast of Portugal on flight A272 between 1548 and 1630 UT on August 31, 1993. CO data are taken from Gerbig et al. [this issue]. 

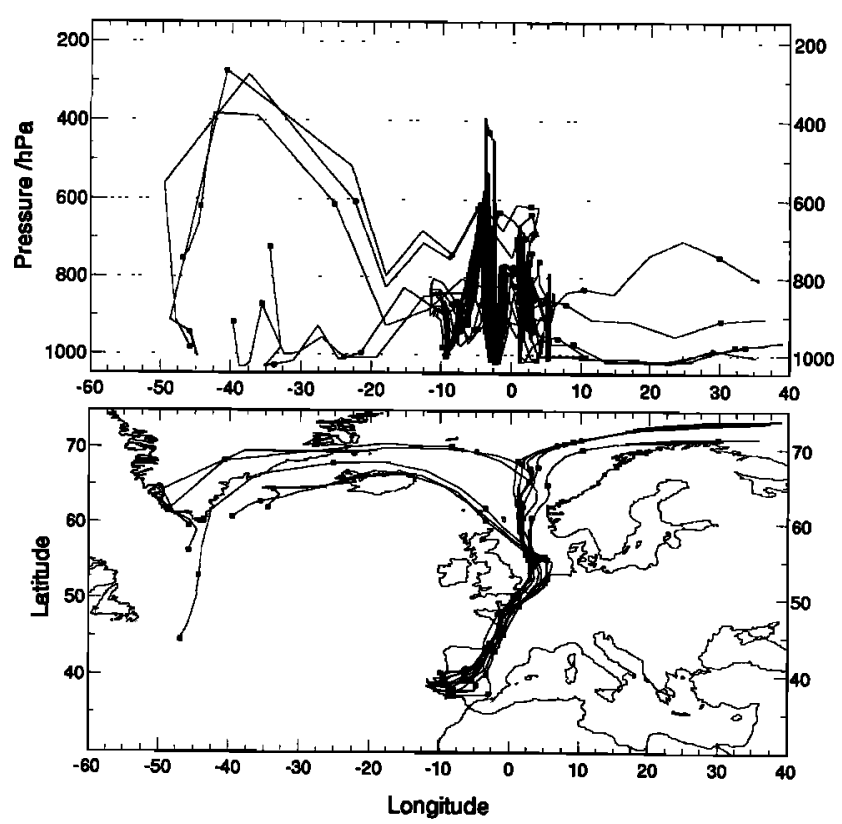

Figure 10a. Ten-day back trajectories arriving at 850 and $900 \mathrm{hPa}$ at the A272 Lisbon profile point at noon on August 31, 1993. Positions are plotted every 6 hours; markers indicate 24-hour intervals.

part in the long-range transport of pollutants. However, although originating in the troposphere, air at this level is potentially open to greater influence from the stratosphere and may therefore affect air masses which subsequently descend through the troposphere, as suggested in the case studies including dilution.

\section{Wind Analyses}

The back trajectory calculation routine uses wind data at a 6-hour resolution with 10 altitude levels below

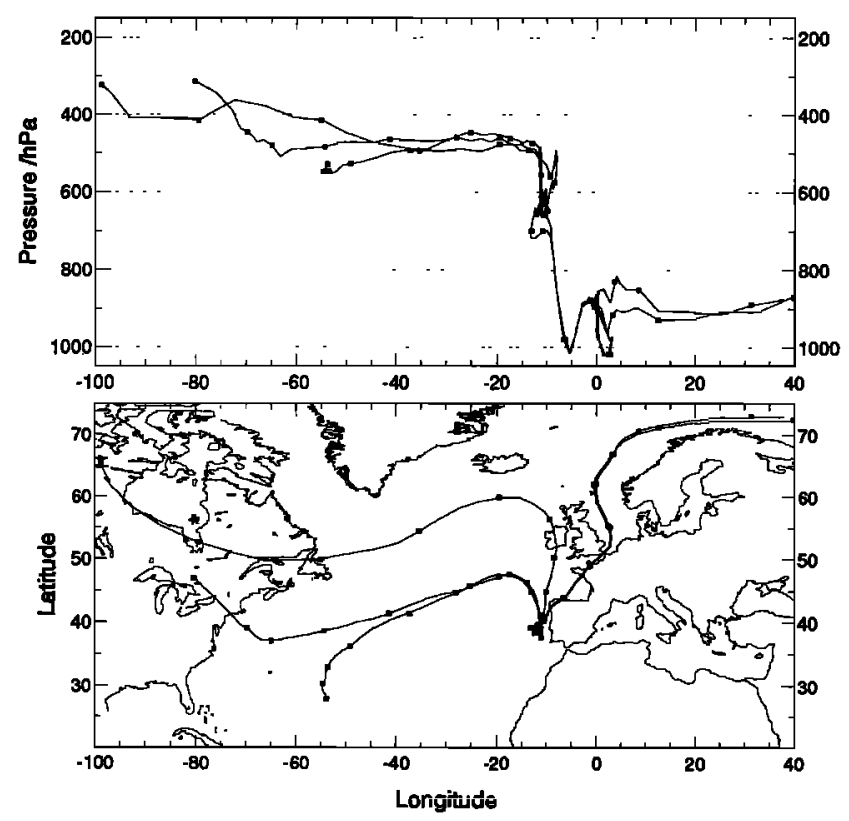

Figure 10b. Ten-day back trajectories arriving at $650 \mathrm{hPa}$ at the A272 Lisbon profile point at noon on August 31, 1993.

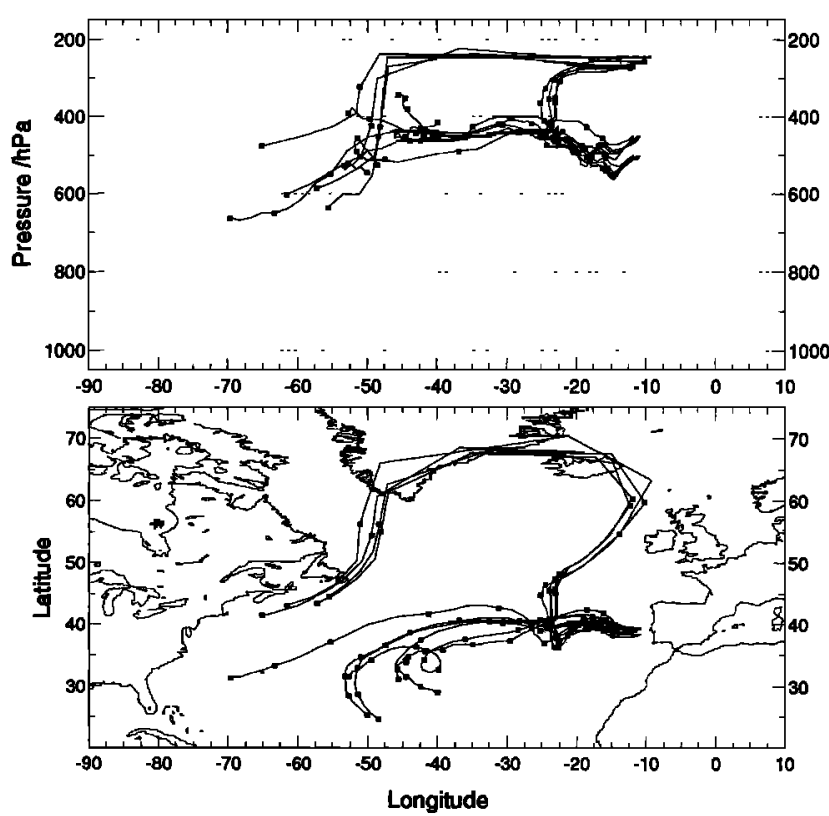

Figure 10c. Ten-day back trajectories arriving at 450 and $500 \mathrm{hPa}$ at the $\mathrm{A} 272$ Lisbon profile point at noon on August 31, 1993.

about $650 \mathrm{hPa}$. To assess the impact of the relatively low spatial and temporal resolution on the local influences, backward trajectories were calculated for a single 6-hour time step from the measurement site, from a grid of points at $1^{\circ}$ intervals in the region around the site. These were assumed to represent the wind directions in the last 6 hours before the profile was taken. Average wind velocities were calculated for the 6 -hour period, assuming a direct path was taken during this step. These are compared with the meteorological data taken from the Hercules aircraft in Figure 11.

The general trend in wind direction with altitude is well reproduced, indicating that local effects are relatively small in the region during this period. The model resolution is insufficient to pick up the variation around $2.6 \mathrm{~km}$ associated with shear at the top of the boundary layer and hence the high degree of stratification in this region. Note also that the subtle changes of wind direction which are associated with elevated $\mathrm{O}_{3}$ levels at 3.2$4.0 \mathrm{~km}$ are not captured. The assumption of a constant air parcel velocity along a direct path leads to an underestimation of the mean velocity that might be expected along a more meandering path, and no consideration has been made of the variability in the wind speed. Localized and short-term effects such as coastal breezes are not considered in this simplistic treatment of mean air parcel motion; note that the largest discrepancies appear in the lowest $1.2 \mathrm{~km}$. Although these discrepancies in the wind strength have implications for the accuracy of the trajectory calculations, the general agreement in wind direction lends some credibility to the calculations. The relatively poor horizontal and temporal resolution in the wind fields is a limiting factor in following specific layers through the atmosphere. The discrepancy 
(a)

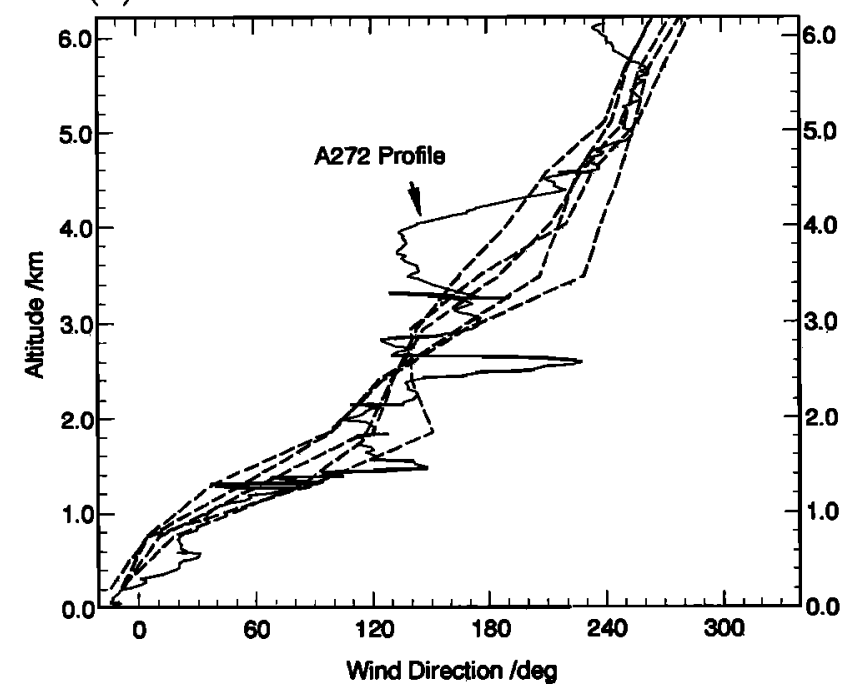

(b)

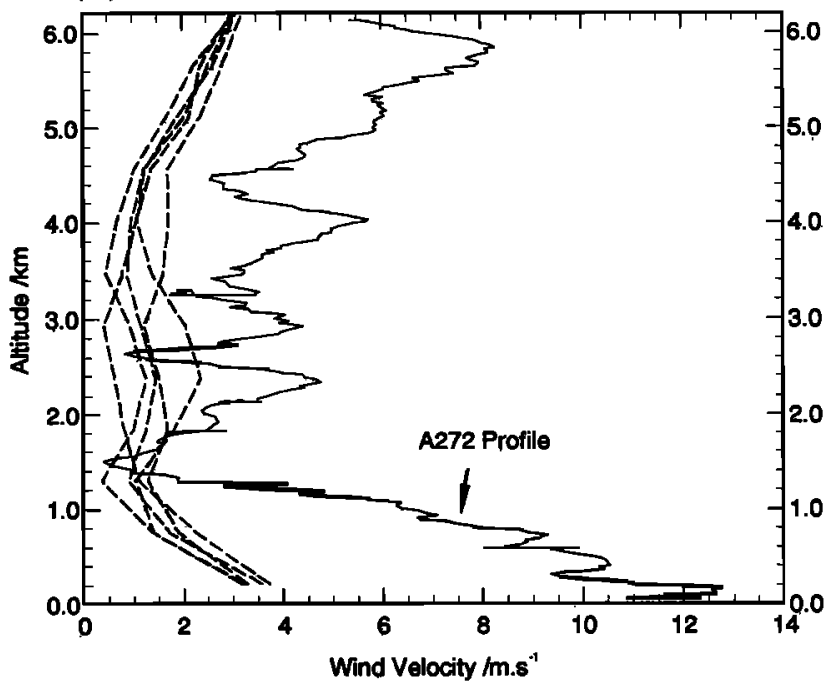

Figure 11. (a) Plots of wind direction and (b) horizontal velocity for the Lisbon profile of flight A272. $0^{\circ}, 90^{\circ}, 180^{\circ}$, and $270^{\circ}$ indicate winds originating from the north, east, south, and west, respectively. Dashed lines refer to trajectories calculated from the profile site and from four points in a $1^{\circ}$ square around it.

just above the boundary layer seen on the Lisbon profile is one example of this, where air with continental influences arrived from the southeast in preference to cleaner air from the southwest. However, the trajectories can be considered to have captured the general features of the mean flow quite well.

\section{Contributions From Europe}

Trajectories arriving at the profile point at levels below $650 \mathrm{hPa}$, about $3.1 \mathrm{~km}$, have spent a significant amount of time in the European boundary layer and are therefore likely to have been exposed to European emission sources. The photochemical model has been run along a representative trajectory to look at the impact of these sources on $\mathrm{O}_{3}$ production below $650 \mathrm{hPa}$ in the region of the profile. Most of the trajectories originate from the North Sea and the European continental boundary layer in the last couple of days before arrival at the profile point, and hence the choice of trajectory to follow is not critical. The effect of fresh emissions over Europe is sufficiently strong to swamp the effect of emissions from any previous sources, reducing the impact of the initial concentrations on the results. A trajectory originating north of Russia was selected, which dips below the mixing height parameterized in the model 3 times over Europe and then rises to $650 \mathrm{hPa}$ for the last two days; see Figure 12a.

The runs were initialized with relatively low concentrations suitable for the subarctic conditions north of Russia, taken from the IPCC continental rural scenario $I P C C$ [1995] (see Table 6), and $\mathrm{NO}_{x}$ and $\mathrm{NMHC}$ emissions over Europe were allowed to influence the air mass when the trajectory passed into the model-defined boundary layer. The model was run under a number of different physical conditions, first with chemistry only, then adding wet and dry deposition, and then including surface emissions in the boundary layer. Finally, a further halved emission rate was included above the boundary layer in addition to the surface emissions. The results are shown in Figure 12b.

The chemistry-only run shows slow $\mathrm{O}_{3}$ formation from the initial $30 \mathrm{ppbv}$ on the first day, followed by slow destruction for the remainder of the 10-day run, reflecting the low $\mathrm{NO}_{x}$ concentrations and high water vapor content. Inclusion of wet and dry deposition leads to a slightly faster $\mathrm{O}_{3}$ loss in the first 5 days due to wet deposition of $\mathrm{HNO}_{3}$ and $\mathrm{H}_{2} \mathrm{O}_{2}$ and hence slower formation of $\mathrm{O}_{3}$ from $\mathrm{NO}+\mathrm{HO}_{2}$ and $\mathrm{NO}+\mathrm{RO}_{2}$. The rapid drop in $\mathrm{O}_{3}$ occurring on the fifth day is due to entry into the boundary layer and subsequent dry deposition at the surface. The air parcel emerges from the boundary layer when the mixing layer collapses at dusk and enters again on the seventh day (day 238). When the parcel leaves the boundary layer and rises over the Pyrenees, the $\mathrm{O}_{3}$ level is effectively preserved at about 8 ppbv.

Inclusion of emissions in the boundary layer results in periods of $\mathrm{O}_{3}$ production during the daytime and periods of $\mathrm{O}_{3}$ destruction at night influenced by high levels of NO and by deposition. On rising out of the boundary layer on the eighth day (day 239), the parcel enters a period of rapid $\mathrm{O}_{3}$ production associated with high $\mathrm{NO}_{x}$ and hydrocarbon levels. The production decreases on successive days as $\mathrm{NO}_{x}$ is depleted by oxidation to $\mathrm{HNO}_{3}$, resulting in an $\mathrm{O}_{3}$ mixing ratio of about $54 \mathrm{ppbv}$ over the eastern Atlantic. Introducing a further $50 \%$ of the surface emissions above the boundary layer, to simulate the effect of transfer out of the boundary layer due to shallow convective events associ- 
(a)

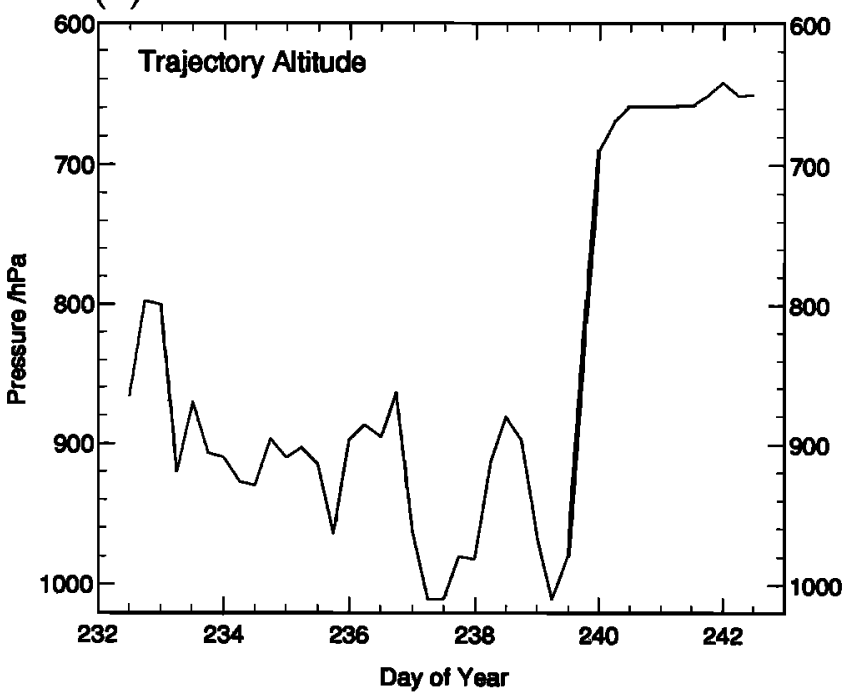

(b)

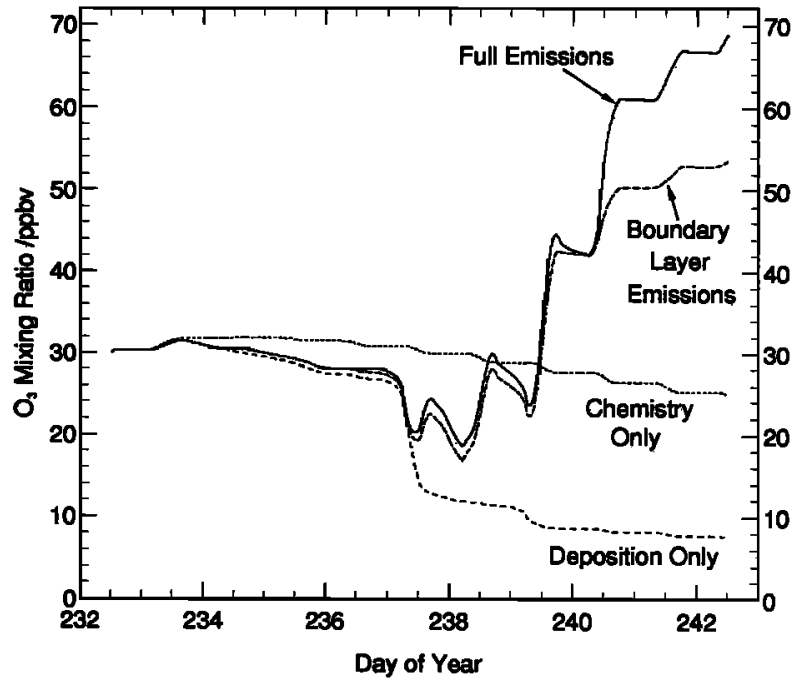

Figure 12. (a) Trajectory altitude and (b) $\mathrm{O}_{3}$ concentrations along a 650-hPa back trajectory crossing Europe and ending at noon at the profile point.

ated with clouds, leads to larger concentrations of $\mathrm{NO}_{x}$ in the air parcel, particularly at the beginning of the ninth day (day 240). This leads to greater $\mathrm{O}_{3}$ production in the last 3 days, with the mixing ratio reaching about $69 \mathrm{ppbv}$ at the profile point off the coast of Portugal.

Mean concentrations from the lower part of the Lisbon profile are shown in Table 7, together with the results of the different model runs. The $\mathrm{CO}$ and $\mathrm{H}_{2} \mathrm{O}_{2}$ levels reveal the polluted nature of this layer, both exceeding the modeled values even in the full emission scenario. The $\mathrm{NO}_{y}$ concentrations are considerably less than either run involving emissions; this may be due to overestimation of $\mathrm{NO}_{x}$ emissions but is probably due principally to the effects of dilution with cleaner background air. Faster dry deposition would reduce the final $\mathrm{NO}_{y}$ concentrations, but faster wet deposition would also be expected to remove significant amounts of $\mathrm{H}_{2} \mathrm{O}_{2}$. The $\mathrm{H}_{2} \mathrm{O}_{2}$ concentrations modeled are already lower than those measured, implying lower $\mathrm{HO}_{2}$ or higher $\mathrm{OH}$ concentrations than measured; this would be consistent with higher $\mathrm{NO}_{2}$ concentrations producing a larger $\mathrm{OH} / \mathrm{HO}_{2}$ ratio. $\mathrm{O}_{3}$ concentrations average $46-50 \mathrm{ppbv}$ in the lowest $2.5 \mathrm{~km}$ of the profile, with the maximum of $57 \mathrm{ppbv}$ occurring in a narrow layer at about $600 \mathrm{~m}$ altitude. The runs including chemistry, deposition, and emissions correspond reasonably well with these measurements. It is likely that the air mass intercepted at this level was originally considerably more polluted than suggested by the full emission scenario, but concentrations were reduced by mixing processes.
However, the general agreement obscures many of the uncertainties present. The principal omission is that of dispersion of the air mass and dilution with air of cleaner origin, which may lead to a lowering of the peak concentrations. The vertical spreading up to $650 \mathrm{hPa}$ is visible from the back trajectories (see Figures 10a and 10b) leading to the relatively uniform levels of $\mathrm{H}_{2} \mathrm{O}_{2}$, water vapor, and aerosol throughout the lower $2.5 \mathrm{~km}$. Evidence of air masses with different chemical histories contributing to this layer can be seen in the stratification of the $\mathrm{O}_{3}, \mathrm{NO}_{y}$, and $\mathrm{CO}$ profiles. The emission rates used are at a coarse resolution, and hence the high degree of variation that would be expected between rural and urban areas has not been captured. Dry deposition rates have been specified for land and ocean environments, but in practice, the rate of deposition is also strongly dependent on the vegetation type over land. In addition, the simple parameterizations used for the mixing height and for wet deposition may have been inappropriate for the specific meteorological conditions of this period. The profile point is over the ocean, and the effects of local meteorological factors such as sea breezes near the coast might also be expected to influence the mixing of air masses at low altitudes. However, note that the distance between the emission sources and the profile point is sufficient that $\mathrm{O}_{3}$ levels are principally dependent on the total $\mathrm{NO}_{x}$ and NMHC loading rather than on the time since emission.

Although the exact path through the atmosphere over Europe and the effects of individual pollution sources are unclear, this study confirms that the excess ozone

Table 6. Initial Chemical Concentrations Used fơr Cioss-Europe Trajectories

\begin{tabular}{cccccccc}
\hline $\mathrm{O}_{3}$ & $\mathrm{CH}_{4}$ & $\mathrm{CO}$ & $\mathrm{H}_{2} \mathrm{O}_{2}$ & $\mathrm{NO}_{x}$ & $\mathrm{HNO}_{3}$ & $\mathrm{H}_{2} \mathrm{O}$ & NMHCs \\
\hline $30 \mathrm{ppbv}$ & $1.7 \mathrm{ppmv}$ & $100 \mathrm{ppbv}$ & $2.0 \mathrm{ppbv}$ & $200 \mathrm{pptv}$ & $100 \mathrm{pptv}$ & $1.0 \%$ & $0 \mathrm{ppbC}$ \\
\hline
\end{tabular}


Table 7. Comparison of Cross-Europe Runs With Measurements Below $650 \mathrm{hPa}$ From the Lisbon Profile on MRF Flight A272

\begin{tabular}{lrrrr}
\hline \multicolumn{1}{c}{ Scenario } & \multicolumn{1}{c}{$\mathrm{O}_{3}$} & \multicolumn{1}{c}{$\mathrm{NO}_{y}$} & \multicolumn{1}{c}{$\mathrm{H}_{2} \mathrm{O}_{2}$} & \multicolumn{1}{c}{$\mathrm{CO}$} \\
\hline Lisbon profile & $45-55 \mathrm{ppbv}$ & $0.60-1.00 \mathrm{ppbv}$ & $2.20-2.80 \mathrm{ppbv}$ & $140-180 \mathrm{ppbv}$ \\
Chemistry only & $25 \mathrm{ppbv}$ & $0.30 \mathrm{ppbv}$ & $1.86 \mathrm{ppbv}$ & $87 \mathrm{ppbv}$ \\
Boundary layer emissions & $53 \mathrm{ppbv}$ & $4.52 \mathrm{ppbv}$ & $2.10 \mathrm{ppbv}$ & $139 \mathrm{ppbv}$ \\
Full emissions & $69 \mathrm{ppbv}$ & $6.65 \mathrm{ppbv}$ & $2.06 \mathrm{ppbv}$ & $157 \mathrm{ppbv}$ \\
\hline
\end{tabular}

amounts observed at low altitudes in the profile can be attributed to the influence of European emissions.

\section{Midtropospheric Air}

The origin of the air mass intercepted at the top of the Lisbon profile is more unclear. Air masses intercepted by the Hercules during the cross-Atlantic flights of August 24 and 28 at this altitude are often above 50 ppbv. Similarly, measurements from Bermuda and the Azores [Oltmans et al., 1994] show typical $\mathrm{O}_{3}$ concentrations of 50-75 ppbv at this altitude, with pulses of enhanced $\mathrm{O}_{3}$ greater than 75 ppbv. While the $\mathrm{O}_{3}$ concentrations measured on the Lisbon profile are not obviously enhanced over these background values, the $\mathrm{NO}_{y}$, $\mathrm{CO}$, and aerosol measurements made at the same time strongly suggest the influence of anthropogenic sources.

The back trajectories at this level originate from the west, and hence influence from European emission sources is highly unlikely. In addition, the water vapor volume mixing ratio is only $0.1 \%$, and hence ascent of European air would have required considerable drying of the air mass. The air could have originated from the upper troposphere, with possible influences from the stratosphere; this would account for higher $\mathrm{O}_{3}$ and $\mathrm{NO}_{y}$ levels. Water vapor content may be increased by transport of this air to lower altitudes for a number of days, but this would not account for the higher $\mathrm{CO}$ concentrations or aerosol without an additional source. Another possibility is that the air could have originated from the lower troposphere over North America. The trajectory calculations indicate that if this was the case then at least part of the transport must have occurred via the upper troposphere as air passed around the highpressure system. The forward trajectories show that air from higher altitudes followed a similar path around the high pressure at $300 \mathrm{hPa}$, and hence it is likely that air from the lower troposphere over North America mixed with air that may have seen influences from the stratosphere.

To what extent can the results of the cross-Atlantic case study be related to the Lisbon profile? It is unlikely that the air mass intercepted by the King Air over the Gulf of Maine is exactly the same as that intercepted off the coast of Portugal by the Hercules 11 days later. However, the King Air measurements have been taken to be representative of polluted plumes leaving North America. A comparison is made with measurements from the upper levels of the A272 Lisbon profile in Table 8 .

Considering photochemistry alone leads to significant underestimation of the removal of all the key species, with the exception of $\mathrm{H}_{2} \mathrm{O}_{2}$; see Table 8. The dilutiononly scenario is clearly dependent on both the choice of background conditions and the selected dilution rate; however, inclusion of any degree of dilution is likely to bring the results into better agreement with the Hercules measurements. None of the species considered is ideal as a measure of the suitability of the dilution rate, as all are affected by the choice of background concentrations to some degree. In addition, species such as $\mathrm{O}_{3}$ are strongly affected by chemical processes. Although $\mathrm{NO}_{y}$ is not affected by chemistry in these studies and background concentrations are assumed very low at $100 \mathrm{pptv}, \mathrm{HNO}_{3}$ and $\mathrm{HNO}_{4}$ are subject to wet deposition, which may well have a significant impact on $\mathrm{NO}_{y}$ levels on a trajectory this long. $\mathrm{CO}$ has a relatively slow chemical loss rate but is rather dependent on the $\mathrm{OH}$ concentrations over the course of the run. $\mathrm{H}_{2} \mathrm{O}_{2}$ is highly dependent on the chemistry as well as on potential loss from wet deposition. The $\mathrm{NO}_{y}$ measurements

Table 8. Comparison of Cross-Atlantic Runs With Measurements at the Top of the Lisbon Profile on MRF Flight A272

\begin{tabular}{lrrrr}
\hline \multicolumn{1}{c}{ Scenario } & \multicolumn{1}{c}{$\mathrm{O}_{3}$} & \multicolumn{1}{c}{$\mathrm{NO}_{y}$} & \multicolumn{1}{c}{$\mathrm{H}_{2} \mathrm{O}_{2}$} & $\mathrm{CO}$ \\
\hline Lisbon profile & $45-55 \mathrm{ppbv}$ & $0.40-0.65 \mathrm{ppbv}$ & $\mathbf{0 . 7 0}-\mathbf{0 . 9 0} \mathrm{ppbv}$ & $90-105 \mathrm{ppbv}$ \\
Chemistry only & $129 \mathrm{ppbv}$ & $15.0 \mathrm{ppbv}$ & $\mathbf{0 . 2 8} \mathrm{ppbv}$ & $194 \mathrm{ppbv}$ \\
Chemistry with slow dilution & $72 \mathrm{ppbv}$ & $1.80 \mathrm{ppbv}$ & $\mathbf{0 . 3 7} \mathrm{ppbv}$ & $83 \mathrm{ppbv}$ \\
Chemistry with rapid dilution & $56 \mathrm{ppbv}$ & $0.33 \mathrm{ppbv}$ & $\mathbf{0 . 3 7} \mathrm{ppbv}$ & $75 \mathrm{ppbv}$ \\
Slow dilution only & $57 \mathrm{ppbv}$ & $1.80 \mathrm{ppbv}$ & $\mathbf{0 . 5 2} \mathrm{ppbv}$ & $78 \mathrm{ppbv}$ \\
Rapid dilution only & $54 \mathrm{ppbv}$ & $0.33 \mathrm{ppbv}$ & $\mathbf{0 . 5 1} \mathrm{ppbv}$ & $76 \mathrm{ppbv}$ \\
\hline
\end{tabular}

Note that the dilution runs use the "stratospheric" scenario background $\mathrm{O}_{3}$ mixing ratios. 
are bracketed by runs at the two dilution rates; assuming that some loss of $\mathrm{NO}_{y}$ by rain-out of $\mathrm{HNO}_{3}$ has occurred, then the slow dilution rate would appear to be the more suitable, accompanied by slightly higher background concentrations. $\mathrm{CO}$ and $\mathrm{H}_{2} \mathrm{O}_{2}$ are both underestimated when dilution is included, suggesting that the background concentrations encountered were higher than those used. Note that chemical destruction of $\mathrm{H}_{2} \mathrm{O}_{2}$ in the present studies leads to concentrations lower than the background values used, and hence dilution leads to an increase in the final volume mixing ratios.

There are many uncertainties in modeling the transport of polluted air across the Atlantic. The forward trajectory used in the present studies arrives in the region of the Hercules profile between 600 and $800 \mathrm{hPa}$, whereas the upper levels of the profile are at about $500 \mathrm{hPa}$. The reliability of trajectories over a 10-day period in the troposphere is uncertain, though clearly dependent on the meteorological conditions for the period. Although the trajectories in the upper and midtroposphere for the final week of August diverge very little as they track around the high pressure and descend along the coast of Europe, little information is available on the rate of mixing between the air masses. Although the trajectory model studies have focused principally on the photochemical transformations taking place in an air mass, comparison with the profile has shown that it is very important to consider the mixing of air parcels with surrounding air. Future modeling studies of this type will need to focus on determining background concentrations and dilution rates from observations and meteorological analyses.

\section{Conditions Over the North Atlantic}

The present studies have shown that polluted air masses from both North America and Europe affect the chemical composition of the troposphere over the North Atlantic. Runs using a photochemical trajectory model have indicated the degree of photochemical $\mathrm{O}_{3}$ production that is possible in a physically isolated air mass originating over polluted source regions, around $80 \mathrm{ppbv}$ over 10 days. In the atmosphere, dilution will reduce the magnitude of this $\mathrm{O}_{3}$ production but at the same time increase the region of influence of the primary pollutants in the original air parcel, leading to net production over a wider area. The nonlinearity of $\mathrm{O}_{3}$ production with reduced levels of precursors means that extrapolation from trajectory model runs is extremely difficult, but the greater efficiency of $\mathrm{O}_{3}$ production per unit $\mathrm{NO}_{x}$ at lower $\mathrm{NO}_{x}$ levels may imply that greater total $\mathrm{O}_{3}$ production over the region could occur with the inclusion of mixing processes. However, the timescale for $\mathrm{O}_{3}$ production is likely to be considerably shorter than the full 10 days seen in the chemistry-only scenario, as $\mathrm{NO}_{x}$ levels become too low to maintain production.
As a consequence of the long transport time, realistic air mass compositions over the eastern Atlantic can be attained without invoking any photochemical processes and by choosing suitable dilution rates and background conditions. However, chemical processes certainly will affect composition during transport over the Atlantic; a more detailed treatment of dilution rates and background conditions awaits a more detailed multiple air parcel approach.

\section{Conclusions}

A Lagrangian photochemical trajectory model has been used to study the chemical changes occurring in air masses crossing the North Atlantic in conditions appropriate to the NARE intensive period in August 1993.

The potential impact of North American emission sources on levels of $\mathrm{O}_{3}$ over the North Atlantic Ocean is maximized by transport of air at high altitudes, in drier conditions and in conditions where mixing of air masses is relatively limited. Transport at high altitudes not only allows polluted air masses to display greater $\mathrm{O}_{3}$ production potential but also reduces transport times due to the higher wind speeds in the region of the jet stream and increases the likelihood of the air being subjected to stratospheric influences. Ascent of polluted air by convection or advection immediately after emission leads to the highest $\mathrm{O}_{3}$ concentrations. Photochemical studies indicate that the level of $\mathrm{NO}_{y}$ is the controlling factor in defining total $\mathrm{O}_{3}$ production, as the formation and photolysis of $\mathrm{HNO}_{3}$ buffers $\mathrm{NO}_{x}$ concentrations. Reduction in $\mathrm{NO}_{y}$ by dilution or deposition is liable to curb $\mathrm{O}_{3}$ production. The nature of photochemical $\mathrm{O}_{3}$ production in the conditions modeled indicates that the oxidative capacity of polluted air may persist long after the primary pollutants have been exhausted.

Dilution of a polluted air mass by background air is shown to exhibit strong control over the final chemical composition with trajectories of the length used here. The final chemical composition is therefore strongly influenced by both the rate of dilution and the background concentrations used to dilute the air mass. In situations where mixing is important, the direct photochemical influence may be smaller than the influence of mixing, even for relatively polluted initial conditions such as those experienced over the Gulf of Maine.

Profiles sampled on the Hercules flights during the OCTA campaign have been considered in the light of the trajectory model sensitivity studies. Off the coast of Portugal, polluted air was intercepted above the surface layer, and both chemical and trajectory analyses indicate that this air mass contained recently polluted air from continental Europe. At the top of the profile, higher levels of $\mathrm{O}_{3}, \mathrm{NO}_{y}$, and $\mathrm{CO}$ were again encountered; the trajectory analysis indicates that they did not originate in Europe and suggests North American origins. However, much of the air leaving North Amer- 
ica is taken up to $300 \mathrm{hPa}$ around the Atlantic highpressure ridge, and hence the influence of stratospheric air masses may be significant. The chemical composition of the air mass indicates that it is not of stratospheric origin, but it is unclear how much mixing may have occurred between polluted air from North America and air in the upper troposphere.

These studies have shown the value of using a Lagrangian approach to model the photochemistry of the troposphere and for assessing secondary pollutant formation. The limitations of this type of approach have also been highlighted, as dilution of plumes by adjacent air masses cannot be fully quantified. However, it is clear from this work that North American sources do indeed affect the midtroposphere over the eastern Atlantic and Europe, as suggested by Parrish et al. [1993]. It is not possible to assess the total $\mathrm{O}_{3}$ production over the North Atlantic in the second half of August 1993 with this type of model. A quantification of the impact of North American and European sources on the oxidizing capacity of the troposphere over the North Atlantic, as applied by Parrish et al. [1993] and Doddridge et al. [1994], awaits a more physically detailed study with a regional three-dimensional model.

Acknowledgments. The authors are grateful to Andreas Volz-Thomas and Christoph Gerbig at KFA Forschungszentrum Jülich for access to the CO data prior to publication and for stimulating discussions, to Paul Berrisford and the ECMWF for supplying wind fields for August 1993, to Anton Eliassen and David Simpson for use of the European EMEP MSC-W (the Norwegian Meteorological Institute) emission data set for 1992, and to Michael Memmesheimer for his parameterization of diurnal and annual variations in the emission data. The authors are also grateful for the comments of two anonymous reviewers. We wish to thank the U.K. Department of the Environment, U.K. Science and Engineering Research Council (O. Wild) and the Commission of the European Union (OCTA, contract EV5V-CT91-0042) for financial support.

\section{References}

Atkinson, R., D. L. Baulch, R. A. Cox, R. F. Hampson, J. A. Kerr, and J. Troe, Evaluated kinetic and photochemical data for atmospheric chemistry, Supplement IV IUPAC Subcommittee on Gas Kinetic Data Evaluation for Atmospheric Chemistry, J. Phys. Chem. Ref. Data, 21, 1125-1568, 1992.

Ayers, G. P., S. A. Penkett, R. W. Gillett, B. Bandy, I. E. Galbally, C. P. Meyer, C. M. Elsworth, S. T. Bentley, and B. W. Forgan, Evidence for photochemical control of ozone concentrations in unpolluted marine air, Nature, 360, 446-449, 1992.

Buhr, M., D. Sueper, M. Trainer, P. Goldan, B. Kuster, and F. Fehsenfeld, Trace gas and aerosol measurements using aircraft data from the North Atlantic Regional Experiment (NARE 1993), J. Geophys. Res., this issue.

Chatfield, R. B., and A. C. Delany, Convection links biomass burning to increased tropical ozone - However, models will tend to overpredict $\mathrm{O}_{3}, J$. Geophys. Res., 95, 18,473$18,488,1990$.

Chin, M., D. J. Jacob, J. W. Munger, D. D. Parrish, and B.
G. Doddridge, Relationship of ozone and carbon monoxide over North America, J. Geophys. Res., 99, 14,565$14,573,1994$.

Chipperfield, M. P., D. Cariolle, P. Simon, R. Ramaroson, and D. J. Lary, A three-dimensional modeling study of trace species in the Arctic lower stratosphere during winter 1989-1990, J. Geophys. Res., 98, 7199-7218, 1993.

Cocks, A. T., and I. S. Fletcher, Possible effects of dispersion on the gas-phase chemistry of power-plant effluents, Atmos. Environ., 16, 667-678, 1982.

DeMore, W. B., S. P. Sander, D. M. Golden, R. F. Hampson, M. J. Kurylo, C. J. Howard, A. R. Ravishankara, C. E. Kolb, and M. J. Molina, Chemical kinetics and photochemical data for use in stratospheric modeling, $J P L$ Publ. 92-20, Jet Propul. Lab., Pasadena, Calif., 1992.

Derwent, R. G., and $\emptyset$. Hov, The potential for secondary pollutant formation in the atmospheric boundary layer in a high pressure situation over England, Atmos. Environ., 16, 655-665, 1982.

Dickerson, R. R., B. G. Doddridge, P. Kelley, and K. P. Rhoads, Large-scale pollution of the atmosphere over the remote Atlantic Ocean: Evidence from Bermuda, J. Geophys. Res., 100, 8945-8952, 1995.

Doddridge, B. G., P. A. Dirmeyer, J. T. Merrill, S. J. Oltmans, and R. R. Dickerson, Interannual variability over the eastern North Atlantic Ocean: Chemical and meteorological evidence for tropical influence on regionalscale transport in the extratropics, J. Geophys. Res., 99, 22,923-22,935, 1994.

Fehsenfeld, F. C., P. Daum, W. R. Leaitch, M. Trainer, D. D. Parrish, and G. Hübler, Transport and processing of $\mathrm{O}_{3}$ and $\mathrm{O}_{3}$ precursors over the North Atlantic: An overview of the 1993 North Atlantic Regional Experiment, $J$. Geophys. Res., this issue.

Gerbig, C., D. Kley, A. Volz-Thomas, J. Kent, K. Dewey, and D. S. McKenna, Fast response resonance fluorescence CO measurements aboard the C-130: Instrument characterization and measurements made during NARE 1993, $J$. Geophys. Res., this issue.

Hough, A. M., The calculation of photolysis rates for use in global tropospheric modelling studies, AERE Rep. $R$ 13259, Her Majesty's Stn. Off., London, 1988.

Hough, A. M., Development of a two-dimensional global tropospheric model: Model chemistry, J. Geophys. Res., 96, 7325-7362, 1991.

Intergovernmental Panel on Climate Change (IPCC), Radiative forcing of climate change and an evaluation of the IPCC IS92 emission scenarios, in Climate Change 1994, edited by J. T. Houghton, L. G. Meira-Filho, J. P. Bruce, H. Lee, B. A. Callander, E. F. Haites, N. Harris, and K. Maskell, Cambridge University Press, New York, 1995.

Law, K. S., and J. A. Pyle, Modeling trace gas budgets in the troposphere, 1, Ozone and odd nitrogen, J. Geophys. Res., 98, 18,377-18,400, 1993.

Levy, H., J. D. Mahlman, W. J. Moxim, and S. C. Liu, Tropospheric ozone: The role of transport, J. Geophys. Res., 90, 3753-3772, 1985.

Logan, J. A., M. J. Prather, S. C. Wofsy, and M. B. McElroy, Tropospheric chemistry: A global perspective, J. Geophys. Res., 86, 7210-7254, 1981.

McKeen, S. A., E. Y. Hsie and S. C. Liu, A study of the dependence of rural ozone on ozone precursors in the eastern United States, J. Geophys. Res., 96, 15,377-15,394, 1991. Memmesheimer, M., J. Tippke, A. Ebel, H. Hass, H. J. Jakobs, and M. Laube, On the use of EMEP emission inventories for European scale air pollution modeling with the EURAD model, paper presented at the EMEP workshop on Photooxidant Modelling for Long-Range Transport in Relation to Abatement Strategies, NILU, Berlin, 16-19 April 1991, 1991. 
Merrill, J. T., and J. L. Moody, Synoptic meteorology and transport during the North Atlantic Regional Experiment (NARE) intensive, J. Geophys. Res., this issue.

Merrill, J. T., M. Uematsu, and R. Bleck, Meteorological analysis of long-range transport of mineral aerosols over the North Pacific, J. Geophys. Res., 94, 8584-8598, 1989.

Milford, J. B., D. F. Gao, S. Sillman, P. Blossey, and A. G. Russell, Total reactive nitrogen $(\mathrm{NO}(y))$ as an indicator of the sensitivity of ozone to reductions in hydrocarbon and $\mathrm{NO}_{x}$ emissions, J. Geophys. Res., 99, 3533-3542, 1994.

Oltmans, S. J., and H. Levy, Seasonal cycle of surface ozone over the western North Atlantic, Nature, 958, 392-394, 1992.

Oltmans, S. J., H. Levy, J. Merrill, J. Moody, E Cuevas, M. Trainer, J. Lathrop, and M. O'Neill, Summer and spring tropospheric ozone profiles over the North Atlantic from ozonesonde measurements (abstract), EOS Trans. AGU, 75(44), Fall Meet. Suppl., p. 92, 1994.

Parrish, D. D., J. S. Holloway, M. Trainer, P. C. Murphy, G. L. Forbes, and F. C. Fehsenfeld, Export of North American ozone pollution to the North Atlantic Ocean, Science, 259, 1436-1439, 1993.

Pickering, K. E., A. M. Thompson, R. R. Dickerson, W. T. Luke, D. P. McNamara, J. P. Greenberg, and P. R. Zimmerman, Model calculations of tropospheric ozone production potential following observed convective events, J. Geophys. Res., 95, 14,049-14,062, 1990.

Pickering, K. E., A. M. Thompson, J. R. Scala, W. K. Tao, J. Simpson, and M. Garstang, Photochemical ozone production in tropical squall line convection during NASA Global Tropospheric Experiment Amazon Boundary Layer Experiment 2A, J. Geophys. Res., 96, 3099-3114, 1991.

Ratcliffe, R. A. S., Review of summer 1993 in the Northern Hemisphere, Weather, 48, 378-379, 1993.
Seinfeld, J. H., Urban air pollution: State of the science, Science, 243, 745-752, 1989.

Simpson, D., Long period modeling of photochemical oxidants in Europe - Model calculations for July 1985, Atmos. Environ., 26A, 1609-1634, 1992.

Stockwell, W. R., P. Middleton, J. S. Chang, and X. Y. Tang, The second generation regional acid deposition model chemical mechanism for regional air-quality modeling, J. Geophys. Res., 95, 16,343-16,367, 1990.

Valentin, K. M., Numerical modelling of the climatological and anthropogenic influences on the chemical composition of the troposphere since the last glacial maximum, Ph.D. thesis, Max Planck Inst. for Chem., Mainz, Germany, 1990.

Volz-Thomas, A., M. Schultz, D. S. McKenna, and R. Schmitt, The project OCTA: A European contribution to NARE (abstract), EOS Trans. $A G U, 75(44)$, Fall Meet. Suppl., p. 113, 1994.

Wild, J. O. F., Some problems in the numerical modelling of tropospheric chemistry, Ph.D. thesis, Univ. of Cambridge, Cambridge, England, 1995.

B. J. Bandy and S. A. Penkett, School of Environmental Sciences, University of East Anglia, Norwich, NR4 7TJ, England.

K. S. Law, J. A. Pyle, and O. Wild (corresponding author), Centre for Atmospheric Science, Department of Chemistry, Lensfield Road, Cambridge, CB2 1DQ, England. D. S. McKenna, Institut für Chemie und Dynamik der Geosphäre (ICG-1), KFA Forschungszentrum Jülich GmbH, D-52425 Jülich, Germany.

(Received May 15, 1995; revised February 23, 1996; accepted March 7, 1996.) 